\title{
An evaluation of the impact of aerosol particles on weather forecasts from a biomass burning aerosol event over the Midwestern United States: observational-based analysis of surface temperature
}

\author{
Jianglong Zhang ${ }^{1}$, Jeffrey S. Reid ${ }^{2}$, Matthew Christensen ${ }^{1}$, and Angela Benedetti ${ }^{3}$ \\ ${ }^{1}$ Department of Atmospheric Sciences, University of North Dakota, Grand Forks, ND, USA \\ ${ }^{2}$ Marine Meteorology Division, Naval Research Laboratory, Monterey, CA, USA \\ ${ }^{3}$ European Centre for Medium-Range Weather Forecasts, Reading, UK
}

Correspondence to: Jianglong Zhang (jzhang@atmos.und.edu)

Received: 10 December 2015 - Published in Atmos. Chem. Phys. Discuss.: 18 January 2016

Revised: 16 April 2016 - Accepted: 23 April 2016 - Published: 27 May 2016

\begin{abstract}
A major continental-scale biomass burning smoke event from 28-30 June 2015, spanning central Canada through the eastern seaboard of the United States, resulted in unforecasted drops in daytime high surface temperatures on the order of $2-5^{\circ} \mathrm{C}$ in the upper Midwest. This event, with strong smoke gradients and largely cloud-free conditions, provides a natural laboratory to study how aerosol radiative effects may influence numerical weather prediction (NWP) forecast outcomes. Here, we describe the nature of this smoke event and evaluate the differences in observed near-surface air temperatures between Bismarck (clear) and Grand Forks (overcast smoke), to evaluate to what degree solar radiation forcing from a smoke plume introduces daytime surface cooling, and how this affects model bias in forecasts and analyses. For this event, mid-visible $(550 \mathrm{~nm})$ smoke aerosol optical thickness (AOT, $\tau$ ) reached values above 5. A direct surface cooling efficiency of $-1.5^{\circ} \mathrm{C}$ per unit AOT (at $550 \mathrm{~nm}, \tau_{550}$ ) was found. A further analysis of European Centre for Medium-Range Weather Forecasts (ECMWF), National Centers for Environmental Prediction (NCEP), United Kingdom Meteorological Office (UKMO) near-surface air temperature forecasts for up to $54 \mathrm{~h}$ as a function of Moderate Resolution Imaging Spectroradiometer (MODIS) Dark Target AOT data across more than 400 surface stations, also indicated the presence of the daytime aerosol direct cooling effect, but suggested a smaller aerosol direct surface cooling efficiency with magnitude on the order of -0.25 to $-1.0^{\circ} \mathrm{C}$ per unit $\tau_{550}$. In addition, using observations from the surface stations, uncertainties in near-
\end{abstract}

surface air temperatures from ECMWF, NCEP, and UKMO model runs are estimated. This study further suggests that significant daily changes in $\tau_{550}$ above 1 , at which the smoke-aerosol-induced direct surface cooling effect could be comparable in magnitude with model uncertainties, are rare events on a global scale. Thus, incorporating a more realistic smoke aerosol field into numerical models is currently less likely to significantly improve the accuracy of near-surface air temperature forecasts. However, regions such as eastern China, eastern Russia, India, and portions of the Saharan and Taklamakan deserts, where significant daily changes in AOTs are more frequent, are likely to benefit from including an accurate aerosol analysis into numerical weather forecasts.

\section{Introduction}

The impacts of aerosol particles on long-term climate variations have been extensively studied from the standpoint of both their direct and indirect effects (e.g., IPCC, 2013). It is frequently hypothesized that aerosol particles impart a radiative perturbation that ultimately can alter overall atmospheric temperature, and consequently boundary layer and flow patterns (e.g., Cook and Highwood, 2004; Jacobson and Kaufman, 2006; Lau and Kim, 2006; Jacobson, 2014; Tesfaye et al., 2015, to name a few). However, the climate impact of aerosol particles is derived from a mosaic of individual aerosol events. Upscaling aerosol effects from individual weather phenomenon to climate requires a thorough un- 
derstanding of the nature of individual aerosol events, how aerosol events relate to other meteorological forcing terms, and the data and model tools used to diagnose outcomes. As one would expect, focus in the community has been towards the direct radiative effects of either climatologically mean aerosol characteristics within climate models, or, on the other extreme, large aerosol outbreaks where the aerosol signal is hopefully clearer and more tractable. But even for severe events, diagnosing the extent of aerosol radiative effects on "real meteorology" is a challenge. Due to model inadequacies, free-running models diverge from the true atmospheric state. Numerical weather prediction (NWP) simulations, on the other hand, in part compensate for aerosol radiative effects through the assimilation of copious amounts of observations. Thus, one method for assessing aerosol impacts on weather is to utilize coupled models or NWP forecasts themselves, searching for indicators of aerosol impacts in short- to medium-range forecasts with well-characterized initial conditions (e.g., Pérez et al., 2006; Chapman et al., 2009; Grell et al., 2011; Ge et al., 2014; Mulcahy et al., 2014; Kolusu et al., 2015; Rémy et al., 2015).

Biomass burning plumes and airborne dust are attractive classes of phenomenon that lend themselves to studies of how aerosol particle radiative effects can perturb the atmosphere. Indeed, smoke and dust plumes can cover intercontinental scales with very high aerosol optical thickness (AOT, $\tau$ ). Smoke is particularly amenable to natural laboratory studies as biomass burning smoke, unlike dust, is largely a shortwave forcing agent, and thus compensating long-wave effects are minimized. The plume nature of smoke also allows a certain degree of control for underlying meteorology, and smoke production is not directly coupled to the meteorology. Finally, smoke can display a range of absorption and thus can vary between being a net warmer and net cooler of the local environment, yet maintain net cooling at the surface. Indeed, effects of significant biomass burning events on local temperatures have long been noted. Through analysis of several significant biomass burning events, Robock (1991) showed a $1-7^{\circ} \mathrm{C}$ decrease in near-surface air temperature with a possible maximum decrease of $20^{\circ} \mathrm{C}$, due to smoke plumes. Using a numerical model, Westphal and Toon (1991) simulated the effects of a massive 1982 fire, deriving surface cooling of $8-10^{\circ} \mathrm{C}$. Other studies have also suggested incorporating aerosol events in numerical weather models for more accurate weather forecasts over aerosol-contaminated regions (e.g., Robock, 1991; Mulcahy et al., 2014).

Integrating aerosol events into weather prediction models has not been an easy task in the past as aerosol particles have high variability in both spatial and temporal domains. Thus far there has been little justification for the computational expense to include aerosol particle radiative effects in operational simulations relative to other areas, such as cloud representation. However, in recent years, breakthrough advancements have been made in both satellite aerosol data and aerosol data assimilation, resulting in the development of both off- and in-line aerosol models at NWP centers (e.g., Tanaka and Chiba, 2005; Zhang et al., 2008; Benedetti et al., 2009; Colarco et al., 2010; Pérez et al., 2011; Kukkonen et al., 2012; Sessions et al., 2015).

From the point of view of satellite aerosol retrievals, regional and global aerosol events have been routinely monitored with the use of both active- and passive-based space borne sensors including Moderate Resolution Imaging Spectroradiometer (MODIS), Multi-angle Imaging SpectroRadiometer (MISR), and Cloud-Aerosol Lidar with Orthogonal Polarization (CALIOP) on a daily basis (e.g., Levy et al., 2013; Kahn et al., 2010; Hsu et al., 2013). From the point of view of modeling, advanced data assimilation schemes, including 2D/3D/4D-Var and ensemble Kalman filter methods, have been applied to assimilate satellite and ground-based observations (e.g., Zhang et al., 2008, 2011, 2014; Benedetti et al., 2009; Schutgens et al., 2010; Collins et al., 2001; Yu et al., 2003; Generoso et al., 2007; Adhikary et al., 2008; Tombette et al., 2008; Niu et al., 2008; Lin et al., 2008; Kahnert, 2008; Pagowski and Grell, 2012; Rubin et al., 2016). The cumulative research progress in both observational- and modeling-based aerosol studies has pushed the research front to the edge of fully incorporating prognostic aerosol fields into weather forecasting models.

In realizing this potential, a few studies have attempted to incorporate advanced aerosol schemes into numerical models for weather forecasting. For example, some earlier studies have used the Weather Research and Forecasting (WRF)Chem model for aerosol-related weather research and forecasting (e.g., Chapman et al., 2009; Grell et al., 2011). Kolusu et al. (2015) studied the impact of biomass burning events on weather forecasts with the use of the UK Met Office Unified Model. However, no significant improvements were reported in weather forecasts after the inclusion of more complicated aerosol representations (e.g., Mulcahy et al., 2014; Kolusu et al., 2015). Most recently, Rémy et al. (2015) studied the radiative feedbacks of dust on boundary layer meteorology and found slight improvements to surface temperature forecasts. The inability to significantly improve weather forecasts via the incorporation of more realistic aerosol data in the forecasting processes from these initial attempts could be from multiple causes. It is possible that improvements in both quality and quantity of aerosol observations are needed. It is also possible that uncertainties from other sources in traditional weather forecasts exceed the benefit of incorporating accurate aerosol features in weather forecasting models. In addition, for regions with persistent aerosol contamination, the effect of aerosol particles on weather forecasts may already, in part, be accounted for through assimilation of temperature data that are already affected by the direct cooling effect of aerosol plumes.

In late June 2015, a rapidly evolving smoke aerosol event in the free troposphere, originating from Canadian boreal fires, provided a near step function in fine-mode AErosol RObotic NETwork (AERONET) $500 \mathrm{~nm}$ AOT $\left(\tau_{500}\right)$ from 


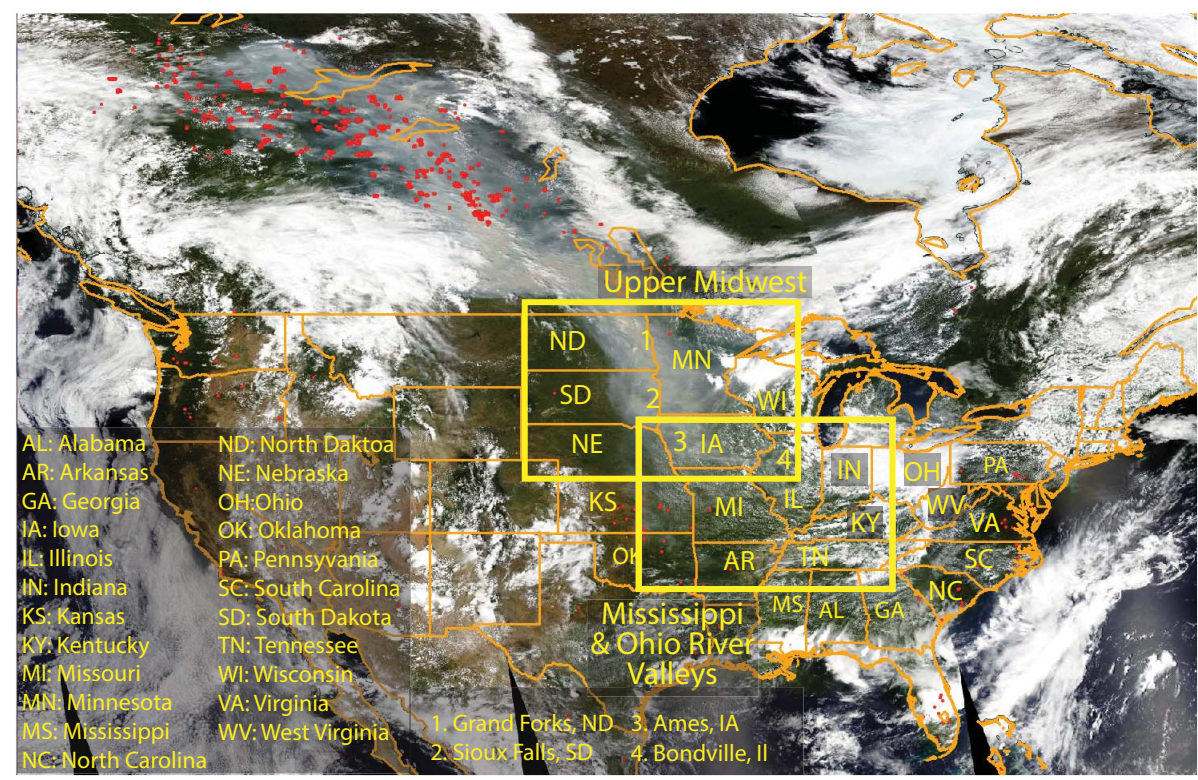

Figure 1. Overview of the study region based on the RGB Aqua MODIS overpass of 29 June 2015 with marking of study domains (yellow boxes) and states referred to in the text. Terra and Aqua fire hotspot detections for that day are also marked in red.

0.1 to over 4 in the upper Midwestern United States (Fig. 1 for a Aqua MODIS RGB regional overview for the peak of the event, Fig. 2 for a MODIS 4 day time series, and Fig. 2e for AERONET observations). This event, when coupled with operational NWP models, provides a natural laboratory for the evaluation of the direct effect of aerosol particles on weather forecasts. The abrupt increase in daily mean aerosol loading was not expected by either weather forecasters or modelers, leading to a noticeable difference between forecasted and observed near-surface air temperatures for 29 and 30 June 2015 as the largely cloud-free smoke plume propagated from Canada through the upper Midwest through the Ohio River Valley (Sect. 3 for details). This event then provided pairs of sites experiencing low vs. high AOT environments. For example, while significant aerosol loading is reported from the Grand Forks AERONET station $\left(\tau_{550}>3\right)$, Bismarck, only $300 \mathrm{~km}$ to the west, experienced low to mild aerosol loading with $\tau_{550}$ of $\sim 0.1-0.4$ as reported from the Collection 6 Terra MODIS Dark Target AOT data. The sharp spatial gradient in aerosol loading makes this case an opportunity for further understanding the effects of smoke aerosol particles on forecasts of surface temperature, and perhaps on any downstream dependencies such as boundary layer height.

This paper is the first of two that explore the NWP implications of the 29-30 June 2015 biomass burning event. Here, we describe the nature of the event and demonstrate the daytime direct cooling effect of smoke aerosol particles on the near-surface air temperature forecasts. This investigation then constrains a follow-up study using the ECMWF forecast model through (a) quantification of the daytime direct aerosol
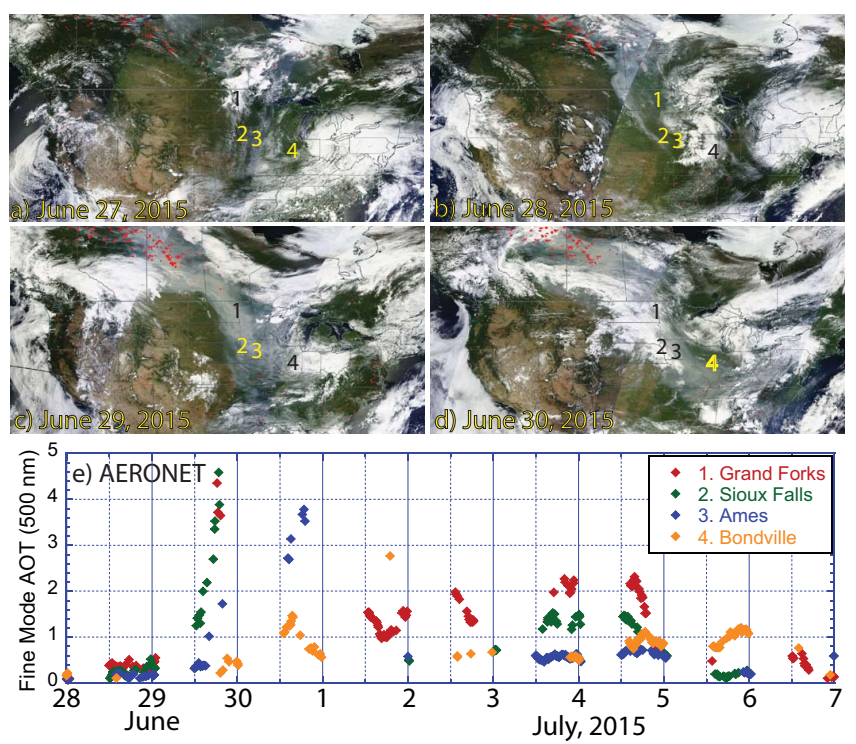

Figure 2. Overview of the 29 June burning event. (a-d) MODIS Terra RGB with daily combined MODIS active fire hotspot detections for 27-30 June. (e) Time series of AERONET fine-mode $\tau_{500}$, sites marked 1-4 indicated on panels (a-d).

effects as a function of altitude and aerosol loading; (b) establishment of the baseline uncertainties in the modeled nearsurface ( 1.5 to $2 \mathrm{~m}$ ) air temperatures over the study domain; and (c) investigation of the conditions under which aerosolinduced cooling effects can be strong enough to significantly alter upper air temperature and downstream dynamical forecasts. 
To meet these objectives, the impact of smoke aerosol particles on the European Centre for Medium-Range Weather Forecasts (ECMWF) $2 \mathrm{~m}$ air temperature forecasts and analyses are studied and regions that could experience noticeable impacts of aerosols on weather forecasts are explored. In addition, statistics are also generated for the National Centers for Environmental Prediction (NCEP) and the United Kingdom Meteorological Office (UKMO) ensemble data sets. This study is predominantly observational-based and describes the overall nature of the event and the observed biases in NWP forecasts. In a companion paper, a sensitivity study using in-line simulations of the ECMWF forecast model is developed to further explore the impacts of smoke aerosols on weather forecasts not only on surface temperatures, but also on any other potential dynamical parameters such as predicted boundary layer height, and geopotential heights and their gradient.

\section{Data sets}

This study focuses on the impact of the 29-30 June smoke event on near-surface air temperature forecasts from three numerical weather prediction models, ECMWF, NOAA NCEP Global Ensemble Forecast System (GEFS), and UKMO Unified Model (UM). It includes their comparison to Automated Surface Observing System (ASOS) surface data and National Weather Service (NWS) forecasted temperature, controlled by AOT as derived from AERONET and MODIS. The data are described below.

\subsection{Aerosol data}

Aerosol optical thickness (AOT) data over the study period are estimated from both regional AERONET station data and Collection 6 (C6) Terra MODIS Dark Target (DT) aerosol products (Levy et al., 2013). AERONET AOTs are derived from the measured solar energy at seven wavelengths including 340, 380, 440, 500, 675, 870, and $1020 \mathrm{~nm}$ (Holben et al., 1998). For the study period, quality-assured Level 2.0 AERONET data are not available, and thus the cloud-screened Level 1.5 AERONET data are used in this study. To derive fine-mode AOT associated with smoke and to help remove any thin cirrus contamination that may be a residual in the level 1.5 data, the Spectral Deconvolution Algorithm as described by O'Neill et al. (2003) and verified by Chew et al. (2011) and Kaku et al. (2014), is utilized. Retrievals of several aerosol-related parameters, including effective radius, spectral single scattering albedo and upwelling and downwelling aerosol forcing efficiencies are also obtained from the AERONET inversion products (Dubovik and King, 2000).

No AERONET data are available at the $550 \mathrm{~nm}$ spectral channel. To be consistent with the MODIS AOT data, AERONET $\tau_{550}$ values are derived by interpolating
AERONET AOTs reported at the 500 and $675 \mu \mathrm{m}$ channels using a method described in Shi et al. (2011). While there are a number of AERONET sites installed in mid-to eastern United States, four observed the nature of the plume particularly well: Grand Forks, North Dakota, $\left(47.91^{\circ} \mathrm{N}\right.$, $\left.97.33^{\circ} \mathrm{W}\right)$; Sioux Fall, South Dakota $\left(43.74^{\circ} \mathrm{N}, 96.63^{\circ} \mathrm{W}\right)$; Ames, Iowa $\left(42.02^{\circ} \mathrm{N}, 93.77^{\circ} \mathrm{W}\right)$, and Bondville, Illinois $\left(40.05^{\circ} \mathrm{N}, 88.37^{\circ} \mathrm{W}\right)$. These are labeled in Figs. 1 and $3 \mathrm{a}$, $\mathrm{c}$ and e, with $500 \mathrm{~nm}$ fine-mode AOTs listed in Fig. 2e.

Over land, MODIS DT aerosol data are available over dark surfaces such as non-desert regions (Levy et al., 2013), and in this study, the Terra MODIS nadir $10 \mathrm{~km}$ resolution $\tau_{550}$ retrievals are used, which best correspond to the midday 12:00 LST/18:00 Z forecast period evaluated. The accuracy of C6 MODIS AOT is reported to be on the order of $0.05+15 \% \times$ AOT (Levy et al., 2013), although individual retrieval uncertainties may be higher (e.g., Shi et al., 2011). As verification, Terra MODIS retrievals were compared to AERONET sites listed above for the period of 29 June through 4 July 2015, with five data points available at Grand Forks having $\tau_{550}$ spanning from 0.88 to 3.7, three at Sioux Falls spanning 0.12 to 3.98, and one at Ames with a $\tau_{550}$ of 0.58 . Regression showed MODIS having a slight 10-20\% high bias, and outstanding regression coefficients $\left(r^{2}=0.98\right)$. However, AOT retrievals failed for $\tau_{550}$ above $\sim 4$ due to saturation of the aerosol signal.

\subsection{Official forecast comparison}

The hypotheses developed for this effort originated from observations of significant temperature forecast errors in the Dakotas in association with the central Canadian smoke plume. Thus a key comparison for forecasted and observed daily maximum temperatures is performed between Grand Forks $\left(47.95^{\circ} \mathrm{N}, 97.18^{\circ} \mathrm{W}\right)$, in the center of the plume, and Bismarck $\left(46.77^{\circ} \mathrm{N}, 100.75^{\circ} \mathrm{W}\right), 300 \mathrm{~km}$ to the west and outside of the plume. These sites are marked in Fig. 3a, c. Official forecast data were obtained from the National Weather Service-issued text weather reports (Point Forecast Matrices and Climate Reports) from the Grand Forks and Bismarck, ND, stations respectively. The NWS Point Forecast Matrices include forecasted daily maximum near-surface air temperatures and other weather conditions. The observed daily maximum surface temperatures are obtained from the NWS Climate Reports which, per the ASOS Users' Guide (http: //www.nws.noaa.gov/asos/aum-toc.pdf, accessed on 29 October 2015) have accuracy at the half degree Celsius level. The archived NWS weather reports from 15 June-14 July 2015 are obtained from the Iowa Environmental Mesonet (IEM) site (https://mesonet.agron.iastate.edu/; Todey et al., 2002), which also hosts the NWS-issued Morning Temperature and Precipitation Summary, from which the observed daily maximum surface temperatures for Roseau $\left(48.86^{\circ} \mathrm{N}\right.$, $\left.95.70^{\circ} \mathrm{W}\right)$ and Baudette $\left(48.73^{\circ} \mathrm{N}, 94.61^{\circ} \mathrm{W}\right), \mathrm{MN}$, were re- 

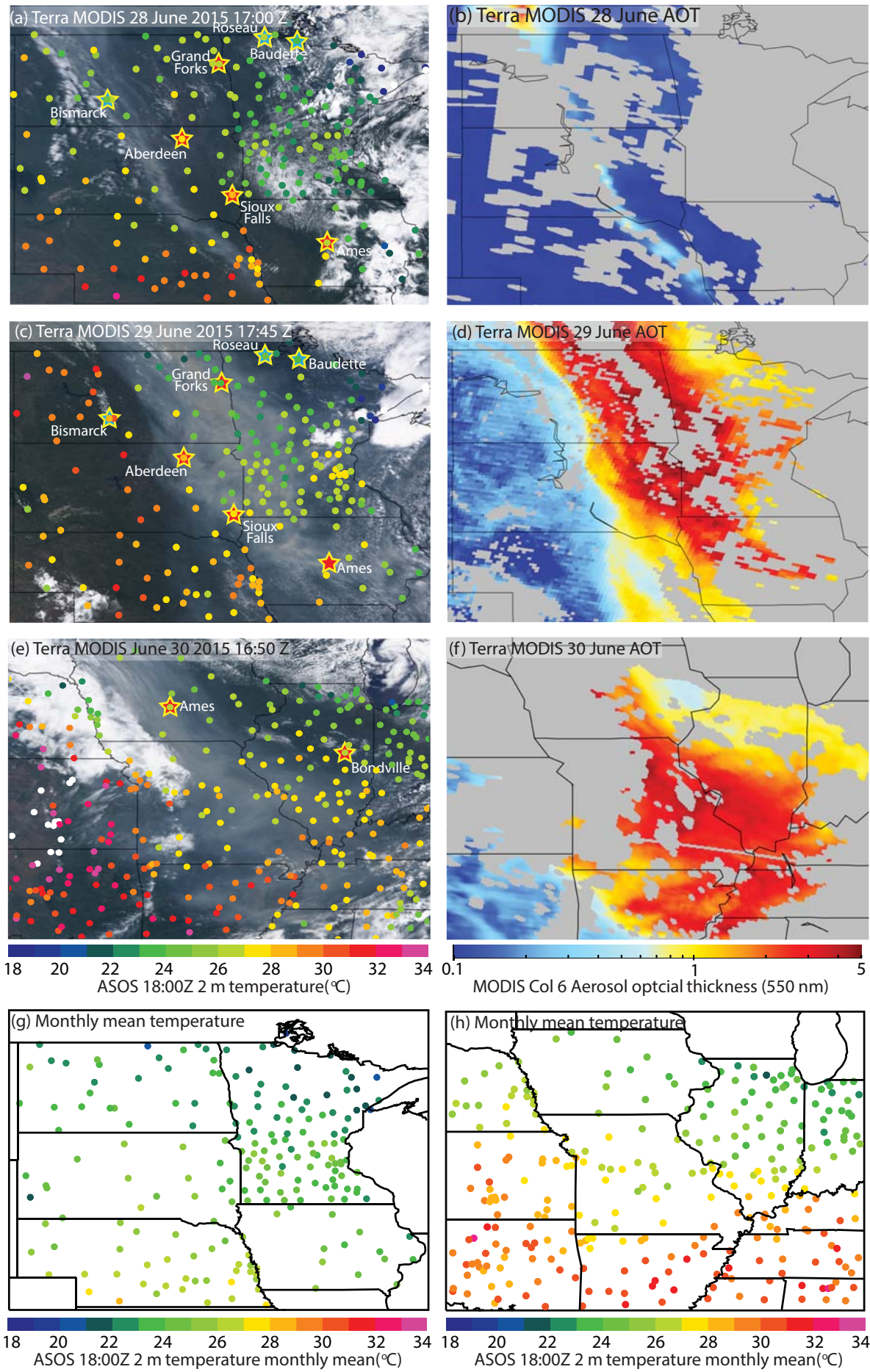

Figure 3. (a, c, e) True color images of a smoke event over the Midwestern United States (28, 29, 30 June 2015, respectively), constructed using the Level $1 \mathrm{~b}$ Terra MODIS data. The ASOS 18:00 Z temperatures are overlaid. Core evaluation sites are labeled; (b, d,f) corresponding $550 \mathrm{~nm}$ aerosol optical thickness from the Collection 6 Terra MODIS aerosol products; (g, h) mean 18:00 Z station temperature \pm 15 days of the event (15 June-14 July 2015. 29 June data are excluded for constructing Fig. 3g, and 30 June data are excluded for constructing Fig. 3h). 
trieved, as these were not available from the NWS Climate Reports.

\subsection{Surface station data}

To supply surface observations for comparisons to forecast models over the greater upper Midwest and Upper Mississippi and Ohio River Valley study area, Automated Surface Observing System (ASOS) surface data are obtained from the Iowa Environmental Mesonet (IEM) site (https:// mesonet.agron.iastate.edu/) for North Dakota, South Dakota, Nebraska, Minnesota, Iowa, Alabama, Arkansas, Illinois, Indiana, Kansas, Kentucky, Missouri, Mississippi, Oklahoma, and Tennessee (Fig. 3a and e). The ASOS data include surface temperature ( $2 \mathrm{~m}$ standard), dew point ( $2 \mathrm{~m}$ standard), wind speed ( $10 \mathrm{~m}$ standard), and direction (10 $\mathrm{m}$ standard) as well as visibility conditions. The surface temperature data used in study have the accuracy on the order of $0.5^{\circ} \mathrm{C}$ for the normal temperature range of -50 to $50^{\circ} \mathrm{C}$ (ASOS user's guide, http://www.nws.noaa.gov/asos/aum-toc.pdf, accessed on 29 October 2015).

\subsection{Forecast model data}

The next step in this analysis was to compare model midday (12:00-13:00 LST, 18:00 Z) surface temperature forecasts with ASOS observations, and relate differences to the location of the smoke plume. 18:00 UTC was selected because it is near local noon and is only $15 \mathrm{~min}$ off the Terra satellite overpass time (17:45 UTC) for North Dakota on 29 June 2015 . The primary model set used for comparison is the deterministic forecasts from ECMWF. Two-meter surface temperate forecasts for the $18: 00 \mathrm{Z}$ valid times $(30$ and $54 \mathrm{~h}$ forecasts) are examined. The 29 and 30 June 2015 18:00 Z forecasts and ASOS observations are examined in detail. The forecast error statistics are also examined for these ASOS sites from 15 June through 14 July.

Model data from the operational version of the European Centre for Medium-Range Weather Forecasts Integrated Forecast System (ECMWF IFS) were used. Forecast data are available 3-hourly from the 00:00 and 12:00 UTC analysis. Analyses are also available at 06:00 and 18:00 UTC from the four-dimensional variational (4D-Var) system with ensemble-generated flow-dependent background error statistics. The current resolution of the ECMWF IFS is approximately $16 \mathrm{~km}$ (T1279 spectral) with 137 vertical levels. More information is available here: https://software.ecmwf.int/ wiki/display/IFS/CY41R1+Official+IFS+Documentation.

In addition to ECMWF, two other model data sets were also examined. Forecast surface temperatures at 24 and $48 \mathrm{~h}$ forecast intervals from the Global Ensemble forecast System (GEFS) UKMO UM ensemble, at 18:00 UTC, were obtained from the THORPEX Interactive Grand Global Ensemble (TIGGE) data archive (Bougeault et al., 2010). The NCEP GEFS data are available on a global scale, with a
Table 1. Missing data for the NCEP model runs. (Data are not available from the TIGGE site.)

\begin{tabular}{ll}
\hline NCEP & Missing data \\
\hline 0 h forecast & 20, 22, 25 June, 5, 14 July \\
24 h forecast & 21, 23, 26 June, 6 July \\
48 h forecast & 22, 24, 27 June, 7 July \\
\hline
\end{tabular}

regridded $0.5 \times 0.5^{\circ}$ (latitude/longitude) spatial resolution at 00:00, 06:00, 12:00, and 18:00 UTC. Gridded statistical interpolation is included as the data assimilation method for the control analysis (http://tigge.ecmwf.int/models.html). The $2 \mathrm{~m}$ air temperatures from the NCEP model runs are used. Note that the NCEP data record is not complete for the selected study period, and missing data are listed in Table 1.

The UKMO data are available at a regridded spatial resolution of $0.5 \times 0.5^{\circ}$ (latitude/longitude) on a global scale. The $4 \mathrm{D}$-Var assimilation scheme is included for the control analysis (http://tigge.ecmwf.int/models.html). The reported $1.5 \mathrm{~m}$ air temperature from the UKMO model runs are used in this study. Other details of the UKMO and NCEP models can be found from Bougeault et al. (2010) and the TIGGE website (http://tigge.ecmwf.int/models.html).

\subsection{Other data and metadata used in this analysis}

To assist the analysis, data from a number of sources are utilized. Descriptions of fire activity were obtained from the Canadian Interagency Forest Fire Center (CIFFC) situation reports (http://www.ciffc.ca/, last accessed 1 December 2015). MODIS fire hotspot data were also used (MOD14/MYD14, Justice et al., 2002). Soundings with temperatures, dew points, and mixing ratios from radiosonde data at Aberdeen, SD, are used $\left(45.45^{\circ} \mathrm{N} ; 98.4^{\circ} \mathrm{W}\right)$. To diagnose lower middle troposphere flow patterns, ECMWF reanalysis was utilized (Dee et al., 2011). Finally to assess the transport trajectory of individual smoke parcels, the Hybrid Single-Particle Lagrangian Integrated Trajectory (HYSPLIT) model (Draxler and Hess, 1997) is also used. The HYSPLIT model computes trajectories of air parcels, both in forward and backward modes, given the geolocation and altitude of an air parcel, as well as model initiation and spinning times.

\section{Results}

\subsection{General description of the June event}

The smoke event described here originated in a set of fires in the Northwest Territories and northern Alberta and Saskatchewan that were initiated $\sim 23$ June 2015, as discussed by CIFFC and observed in MODIS fire hotspot anomalies. These fires were likely the result of lighting in 
association with widespread thunderstorm activity in central Canada lasting several days. By 27 June 2015 (Fig. 2a), over 60 individual fires or complexes were visible in the MODIS fire product, with over 30 fires reported greater than $1000 \mathrm{Ha}$ by the CIFFC. 28 June 2015 MODIS imagery (Fig. 2b) showed significantly enhanced fire activity, with thick palls of smoke being visible over central Canada. Comparison of MODIS fire to the CIFFC suggests that a number of major fire complexes were missed in the satellite product, with significant burning being missed in central Saskatchewan and Manitoba. Nevertheless the dense smoke was present. By 29 and 30 June, smoke was clearly being transported across the Midwest, through the Upper Mississippi and Ohio River Valley, and into the Carolinas.

The rapid transport of this smoke event was related to a persistent long-wave high over the western United States, and corresponding trough over the eastern seaboard. The resulting lower free tropospheric winds were westnorthwesterly (e.g., see $700 \mathrm{hPa}$ height and wind analysis from the ECMWF reanalysis in Fig. 4). These winds veered to north-northwest at $500 \mathrm{hPa}$.

Thus, smoke was channeled into the upper Midwest from central Canada. Smoke transport was further enhanced by a fast-moving shortwave and cold front, with $700 \mathrm{hPa}$ winds at $\sim 25 \mathrm{~m} \mathrm{~s}^{-1}$ (evident from the upper Great Lakes through Iowa and Nebraska in Fig. 4a). This shortwave resulted in the first tongue of smoke entering the United States through central North and South Dakota on 28 June (Fig. 2b). The most dramatic day, 29 June 2015, saw the rapid transport of the major smoke pall from northern Canada into the central Midwest behind the aforementioned shortwave with midvisible AOTs in the upper Midwest above 4 (Fig. 2c and e). Embedded in this smoke event were a set of smaller disturbances and associated wind enhancements across south central Canada and the upper Midwest (Fig. 4b). At the core 18:00 Z analysis time for this study, peak winds associated with the shortwave ranged from west-northwesterly $10 \mathrm{~m} \mathrm{~s}^{-1}$ at $950 \mathrm{hPa}$, veering to northwesterly to $25 \mathrm{~m} \mathrm{~s}^{-1}$ at $500 \mathrm{hPa}$.

A major shift in the pattern occurred on 30 June. Smoke from the previous day had now advected into the Upper Mississippi and Ohio River Valley. Indeed, HYSPLIT trajectories suggest smoke over Grand Forks should have advected to South Central Illinois within $24 \mathrm{~h}$. At the same time, a low and occluded front moved into the Dakotas, bringing heavy cloud cover, some rain, and more zonal winds (Figs. 2d, 4c). At the same time, observed fire activity diminished. Over the first week of July, while smoke was still clearly present at moderately high levels in the upper Midwest (Fig. 2e), the plume structure was not as nearly dramatic. Smoke was also frequently embedded in cloud layers. By 6 July, a significant cold front moved through the area, largely putting the smoke event to an end (e.g., Fig. 2e). From 23 June-9 July, CIFFC reported that $\sim 2000000 \mathrm{Ha}$ were burned.
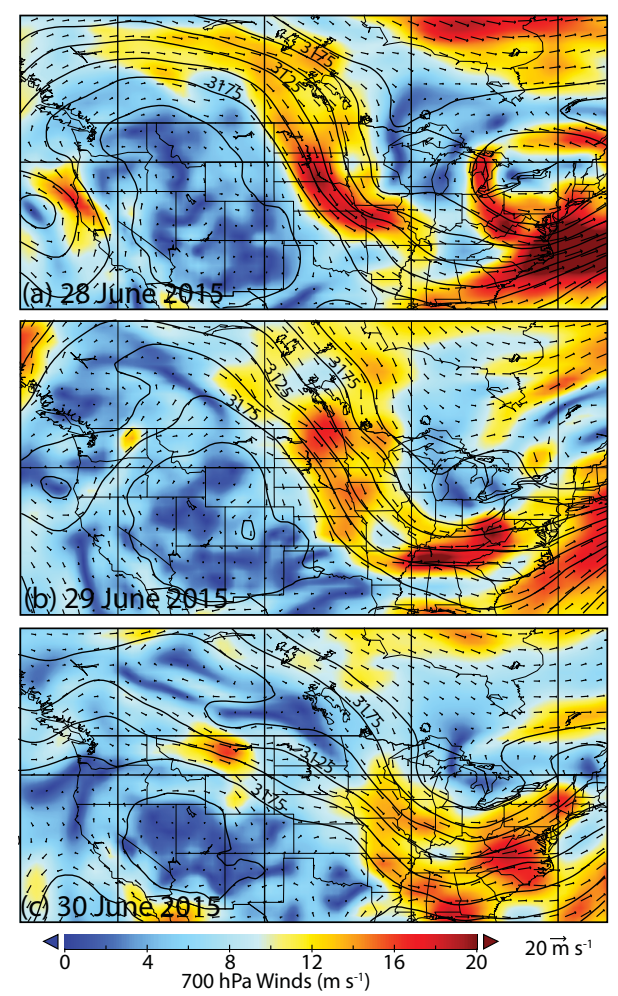

Figure 4. ECMWF Reanalysis of $700 \mathrm{hPa}$ geopotential heights overlayed on winds for (a) 28, (b) 29, and (c) 30 June 2015 at 18:00 Z.

Operational radiosonde releases within the 29-30 June main smoke event are rare due to the unfortunate trajectory of the main plume, perfectly between the Bismarck and International Falls stations in the north and the Omaha/Topeka/Springfield corridor and Chahassen/Davenport/Lincoln corridor in the south. Further, the 00:00 Z and 12:00 $\mathrm{Z}$ releases are nominally in the plume region in the morning and evening. However, there were two radiosondes related to the event, collected under cloud-free sky conditions, the 29 June 12:00 Z and 30 June 00:00 Z release at Aberdeen (Fig. 5). Even though the site is on the edge of the main plume, the MODIS-inferred $\tau_{550}$ was still high $\sim 2$. Clearly, the soundings are dry, with temperature and dew point profiles indicative of relative humidity on the order of $40-50 \%$. Water vapor mixing ratios dropped to below $2 \mathrm{~g} \mathrm{~kg}^{-1}$, by $600 \mathrm{hPa}$, or $4 \mathrm{~km}$.

Unfortunately for ascertaining plume altitudes for this event, no Cloud-Aerosol Lidar with Orthogonal Polarization (CALIOP) lidar data are available until 30 June due to solar flare activity. Over the remaining days, orbit and clouds prevented clear operations across the axis of the plume. However, we can infer from the early morning and afternoon 1 July overpasses over the east coast that this plume was largely below $5 \mathrm{~km}$ in altitude. This is corroborated by the Aberdeen sounding, which showed very low water vapor 
Table 2. Averaged aerosol-related properties, including effective radius $\left(r_{\text {eff }}\right)$, upwelling and downwelling aerosol forcing efficiencies (at $500 \mathrm{~nm}$ ), and single scattering albedo (SSA), corresponding to Dubovik retrievals from measurements from four selected AERONET stations for 29 June-3 July 2015.

\begin{tabular}{lrrrr}
\hline & Grand Forks & Sioux Falls & Ames & Bondville \\
\hline$N$ & 7 & 7 & 11 & 5 \\
AOT $(500 \mathrm{~nm})$ & $1.4 \pm 0.6$ & $1.3 \pm 0.16$ & $0.5 \pm 0.12$ & $0.8 \pm 0.4$ \\
$r_{\text {eff }}(\mu \mathrm{m})$ & $0.162 \pm 0.017$ & $0.164 \pm 0.017$ & $0.160 \pm 0.012$ & $0.170 \pm 0.013$ \\
Up. Forcing Eff. & $-50 \pm 5$ & $-48 \pm 12$ & $-55 \pm 10$ & $-58 \pm 9$ \\
$\left(\mathrm{~W} \mathrm{~m}^{-2} \tau_{500}^{-1}\right)$ & & & & \\
Down Forcing Eff. & $-118 \pm 16$ & $-122 \pm 15$ & $-165 \pm 27$ & $-124 \pm 10$ \\
$\left(\mathrm{~W} \mathrm{~m}{ }^{-2} \tau_{500}^{-1}\right)$ & & & & \\
SSA $(440 \mathrm{~nm})$ & $0.94 \pm 0.01$ & $0.94 \pm 0.01$ & $0.93 \pm 0.01$ & $0.95 \pm 0.01$ \\
SSA $(670 \mathrm{~nm})$ & $0.94 \pm 0.02$ & $0.93 \pm 0.02$ & $0.91 \pm 0.02$ & $0.95 \pm 0.02$ \\
SSA $(870 \mathrm{~nm})$ & $0.93 \pm 0.03$ & $0.92 \pm 0.03$ & $0.88 \pm 0.02$ & $0.94 \pm 0.01$ \\
SSA $(1020 \mathrm{~nm})$ & $0.92 \pm 0.03$ & $0.92 \pm 0.03$ & $0.86 \pm 0.03$ & $0.93 \pm 0.01$ \\
\hline
\end{tabular}

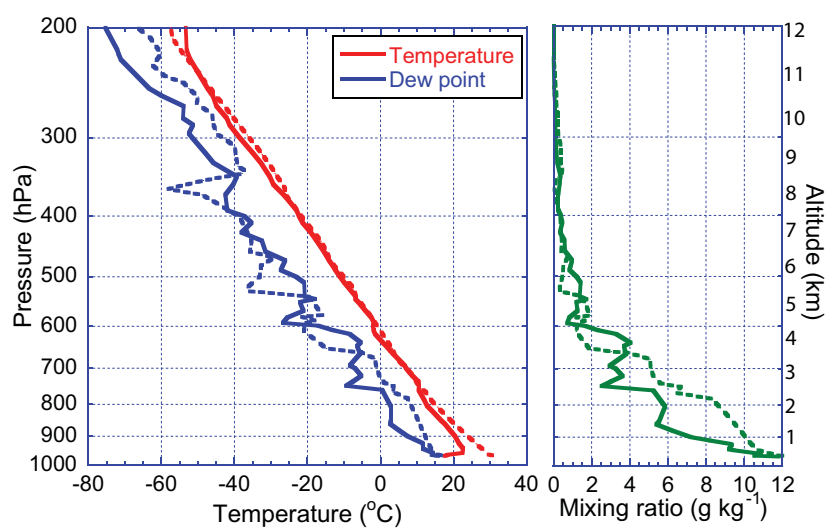

Figure 5. Radiosonde release for Aberdeen, South Dakota, for 29 June 12:00 Z (solid) and 30 June 00:00 Z (dashed).

mixing ratios above $4 \mathrm{~km}$ in altitude. In regard to smoke base, despite the very high AOTs, surface $\mathrm{PM}_{10}$ measurements hardly registered the plume passage. Based on all of the above information, we are confident that the plume was confined to the lower to middle free troposphere.

Estimates of particle size and optical properties of the smoke plume were retrieved from the four core AERONET sites used in this analysis (Table 2). These retrievals were collected from 29 June-3 July over the study area. Particle sizes were fairly stable over the United States, with an effective radius of $\sim 0.165 \mu \mathrm{m}$, or a volume median diameter of $\sim 0.38 \mu \mathrm{m}$. This value is large in comparison to more typical boreal fires (e.g., Reid et al., 2005), but well within values found for mega events from Canada (e.g., 2002 Quebec fire with $\tau_{550}>5$; Colarco et al., 2004; O'Neill et al., 2005). Retrieved single scattering albedo was also consistent and within expected values, $\sim 0.94$ in the mid-visible. In regard to this analysis of surface temperature, what we are most interested in is forcing efficiencies, which ranged from -48 to $-58 \mathrm{~W} \mathrm{~m}^{-2} \tau_{550}^{-1}$ for the top of the atmosphere. For retrieved surface forcing efficiencies, values varied more between sites. Grand Forks, Sioux City, and Bondville all agreed well, ranging from -118 to $-124 \mathrm{~W} \mathrm{~m}^{-2} \tau_{550}^{-1}$. Note that top-of-atmosphere (TOA) (surface) aerosol forcing efficiency is defined as the amount of change in upward (downward) shortwave radiation at TOA (surface) for a unit change in AOT. Negative surface aerosol forcing efficiencies indicate a reduction in shortwave radiation reaching the surface and mostly likely linkage to a decrease in surface temperature. However the Ames site had several outlier retrievals, leading to a higher magnitude downward forcing efficiency of $-165 \mathrm{~W} \mathrm{~m}^{-2} \tau_{550}^{-1}$, due to noticeably lower near-infrared single scattering albedos and slightly smaller size. This departure was consistent through the event. One explanation of this difference between Ames and other sites is that the averaged AOT $(0.5 \mu \mathrm{m})$ is around 0.5 for the Ames site, whereas the averaged AOT $(0.5 \mu \mathrm{m})$ for the other sites ranges from 0.8 to 1.4 (Table 2). Thus, sampling bias is likely a factor.

\subsection{Observed temperature patterns in association with the 29-30 June event}

Figure 3a, c, and e show the RGB true color images of the smoke event over the upper Midwestern United States on 28 June (17:00 and 17:05 UTC) and 29 June (17:45 UTC), and over the Upper Mississippi and Ohio River Valley on 30 June (16:50 and 16:55 UTC), constructed using the Collection 6, Level 1b Terra MODIS data. Figure 3b, d, and $\mathrm{f}$ show the corresponding Terra MODIS C6 DT $\tau_{550}$ for the same study periods as Fig. 3a, c, and e. The observed surface temperatures reported from ASOS stations are overplotted on Fig. 3a, c, and e from North Dakota, South Dakota, Nebraska, Minnesota, and Iowa on 28 and 29 June, and from Alabama, Arkansas, Iowa, Illinois, Indiana, Kansas, Kentucky, Missouri, Mississippi, Nebraska, Oklahoma and Tennessee on 30 June. Each data point in Fig. 3a, c, and e represent the 
averaged observations within $\pm 10 \mathrm{~min}$ from 18:00 UTC of each given day for a given station. The observations from 18:00 UTC are selected as both model analyses and forecasts are available at this time, enabling us to further explore differences between modeled and observed surface temperatures with respect to smoke aerosol properties.

Shown in Fig. 3a, on 28 June, is a stripe of smoke aerosol plume which starts to appear over the upper Midwest region. The overall aerosol loadings are still relatively low $\left(\tau_{550}<0.8\right.$ for the stripe of plume and less than 0.2 for most other regions) across the domain. A mild temperature difference on the order of $1-2{ }^{\circ} \mathrm{C}$ is observed between eastern and western North Dakota. In comparison, on 29 June, a thick smoke plume is observed over the eastern Dakotas and western Minnesota with significant MODIS DT $\tau_{550}$ values of $2-5$. While warmer surface temperatures of $27-32^{\circ} \mathrm{C}$ are observed over the Western Dakotas where lighter aerosol loadings (less than 0.6 ) are found, surface temperatures of $22-24.5^{\circ} \mathrm{C}$ are found over the eastern Dakotas and western Minnesota. The sharp spatial gradient in surface temperature on the order of $5^{\circ} \mathrm{C}$ between eastern and western North Dakota on 29 June 2015, matching the smoke plume pattern, shows the potential influence of the smoke aerosol particles on the observed surface temperatures.

On 30 June, the smoke plume migrates to the Upper Mississippi and Ohio River Valley, as shown in Fig. 3e and $\mathrm{f}$. Note that surface observations are obtained around 18:00 UTC, and the Terra MODIS overpasses are 16:50 16:55 UTC. Thus, there is $\sim 1 \mathrm{~h}$ difference between surfaceand satellite-based observations. Still, as shown in Fig. 3e, especially over Missouri (Center of Fig. 3e), lower surface temperatures are visible over regions with heavy aerosol loadings, which again, reinforces the finding from the 29 June case.

\subsection{Impacts of the smoke plume on an operational weather forecast}

To assess the degree to which the smoke event impacted forecast temperatures, we first performed a hand analysis of the difference in forecast and observed surface temperatures between Grand Forks and Bismarck as reported from the National Weather Service for 29 June. These two sites correspond to the middle and just outside of the main plume. Figure 6 shows the forecast maximum surface air temperatures up to $96 \mathrm{~h}$ for Grand Forks and Bismarck for 29 June 2015. Filled diamonds represent forecast update time. The final daily maximum temperatures, nominally 25.6 and $33.3^{\circ} \mathrm{C}$ for Grand Forks and Bismarck respectively, are also shown. For 29 June, an $\sim 8^{\circ} \mathrm{C}$ difference is seen between sites in and out of the plume even though, typically, the high temperatures between Grand Forks and Bismarck are highly correlated. For the month surrounding the event (15 June-14 July, excluding 29 June), Bismarck was historically warmer than Grand Forks by $1.0 \pm 2.0^{\circ} \mathrm{C}$, with a correlation of 0.90 . Fore-

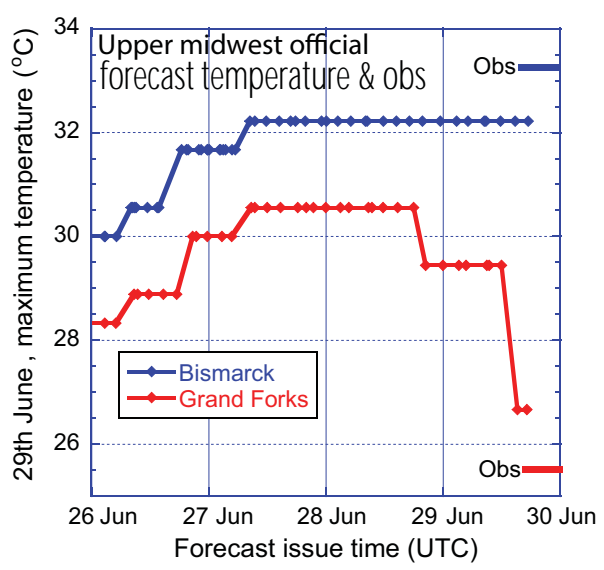

Figure 6. The forecasted daily maximum temperatures from Grand Forks and Bismarck National Weather Service offices as a function of forecasting hours. Short lines on the top and bottom of the righthand side of the figure represent observed daily maximum temperatures for the two stations on 29 June 2015.

casters are well aware of this natural difference and hence account for it in their forecasts. It is also noteworthy that while the daily maximum near-surface air temperature forecasts for 29 June remain unchanged since 27 June for Bismarck, the Grand Forks NWS made a $-2.8^{\circ} \mathrm{C}\left(-5^{\circ} \mathrm{F}\right)$ adjustment for their daily maximum near-surface air temperature forecast at around 10:00 local time on 29 June 2015, possibly to compensate for the initial unexpected surface cooling due to the thick smoke aerosol plume. Despite the higher winds in the lower to middle free troposphere, 29 June was a relatively calm day with moderate winds at the surface, $\left(\sim 3-5 \mathrm{~m} \mathrm{~s}^{-1}\right)$. Taking all of the above factors into consideration, it is hypothesized that the smoke plume with an AERONET-reported daily mean $\tau_{550}$ of $\sim 3.4$ introduced a surface temperature cooling for Grand Forks of $\sim 5^{\circ} \mathrm{C}$. This is equivalent to a daytime aerosol cooling efficiency of $\sim-1.5^{\circ} \mathrm{C} / \tau_{550}$, given that the daily averaged $\tau_{550}$ is 3.4 as reported from Grand Forks AERONET station. Meanwhile, the reported MODIS $\tau_{550}$ value over Bismarck was $\sim 0.35$.

While observations from Bismarck and Grand Forks represent measurements at the diffuse western edge and the central smoke plume, Roseau and Baudette, MN, which are close to Grand Forks, are selected to represent the eastern diffuse edge of the smoke plume. As listed in Table 3, $\tau_{550}$ values are 0.84 and 1.06 for Roseau and Baudette respectively at 17:45 UTC, 29 June 2015, as approximated from MODIS DT retrievals. Note that using the observed surface temperature differences between Grand Forks and the two selected cities in $\mathrm{MN}$ for evaluating aerosol direct cooling effect is not ideal, as surface temperatures from Roseau and Baudette may also be modulated by nearby lakes. Further, lower correlations in daily maximum temperatures, around 0.85 , are found between Grand Forks and the other two locations in MN. Still, Grand Forks is around $2{ }^{\circ} \mathrm{C}$ warmer than 
Table 3. The monthly mean differences $(\Delta T)$ as well as correlations in the observed daily maximum temperatures between Grand Forks, ND (GFK) and three ASOS site: Bismarck, ND (west of GFK), Roseau and Baudette, MN (east of GFK) for 15 June-14 July 2015 , excluding 29 June 2015. The daily maximum temperature differences $(\Delta T)$ between GFK and other three ASOS sites on 29 June 2015 are also reported. Also included are the latitude, longitude of the three ASOS sites and estimated $\tau_{550}$ values from MODIS (17:47 UTC, $550 \mathrm{~nm}$ ).

\begin{tabular}{llrrrrrr}
\hline Location & $\begin{array}{l}\text { Relative to the } \\
\text { GFK site }\end{array}$ & $\begin{array}{r}\text { Lat. } \\
\left({ }^{\circ}\right)\end{array}$ & $\begin{array}{r}\text { Long. } \\
\left({ }^{\circ}\right)\end{array}$ & $R^{2}$ & $\begin{array}{r}\text { MODIS } \tau_{550} \\
17: 47 \mathrm{Z}\end{array}$ & $\begin{array}{r}\text { Mean } \Delta T \\
\left({ }^{\circ} \mathrm{C}\right)\end{array}$ & $\begin{array}{r}\Delta T\left({ }^{\circ} \mathrm{C}\right) \\
(29 \mathrm{June})\end{array}$ \\
\hline Bismarck, ND & West & 46.8 & -100.7 & 0.81 & 0.35 & $-1.0 \pm 2.0$ & -7.8 \\
Roseau, MN & East & 48.9 & -95.7 & 0.72 & 0.84 & $1.9 \pm 2.1$ & -0.6 \\
Baudette, MN & East & 48.7 & -94.6 & 0.73 & 1.06 & $1.8 \pm 2.1$ & 1.1 \\
\hline
\end{tabular}

Roseau and Baudette on a monthly average (Table 3). However, on 29 June 2015, a much smaller temperature difference of $1.1{ }^{\circ} \mathrm{C}$ is found between Grand Forks and Baudette, and Roseau is actually $0.6^{\circ} \mathrm{C}$ warmer than Grand Forks. Both cases may indicate the potential smoke cooling effect. It is noteworthy that the NWS made a $-1.7^{\circ} \mathrm{C}\left(-3^{\circ} \mathrm{F}\right)$ adjustment for the forecasted daily maximum temperatures on 29 June 2015 for both Roseau and Baudette, MN, possibly to compensate for the unexpected smoke-aerosol-induced surface cooling. Lastly, besides the aerosol direct surface cooling effects, surface temperatures could also be impacted by differences in dynamical environments, which adds uncertainties to the study.

\subsection{Impacts of the smoke plume on numerical model predictions}

The above hand analysis provides a benchmark estimate of the cooling efficiency of the Canadian smoke plume. To test this value through an objective analysis, we compared this finding to surface forecast errors focusing on the ECMWF models, starting with the 29 June case. After this analysis, we extended the study to the NCEP and UKMO models and for the 30 June case as well. A synopsis of findings is provided in Fig. 7, where we show (a) the relationship between recorded 18:00 Z temperature to MODIS $\tau_{550}$; (b) the difference of ASOS observation to ECMWF $30 \mathrm{~h}$ forecast against $\tau_{550}$; and (c) and (d), the corresponding overlay of observation minus ECMWF $30 \mathrm{~h}$ forecast mapped over the 29 and 30 June investigation domains. The plots are generated using measurements from ground stations as shown in Fig. $3 \mathrm{c}$ and e. In addition, over the center of the smoke-aerosol-polluted regions, the smoke plume is so optically thick that the MODIS aerosol retrieval scheme failed to report $\tau_{550}$ values. Thus, the closest MODIS $\tau_{550}$ value within $1^{\circ}$ latitude/longitude of a given ground station is used to represent the $\tau_{550}$ value of that station where there is no MODIS aerosol retrieval available. Note that this assumption may introduce a bias in the estimated MODIS AOTs.
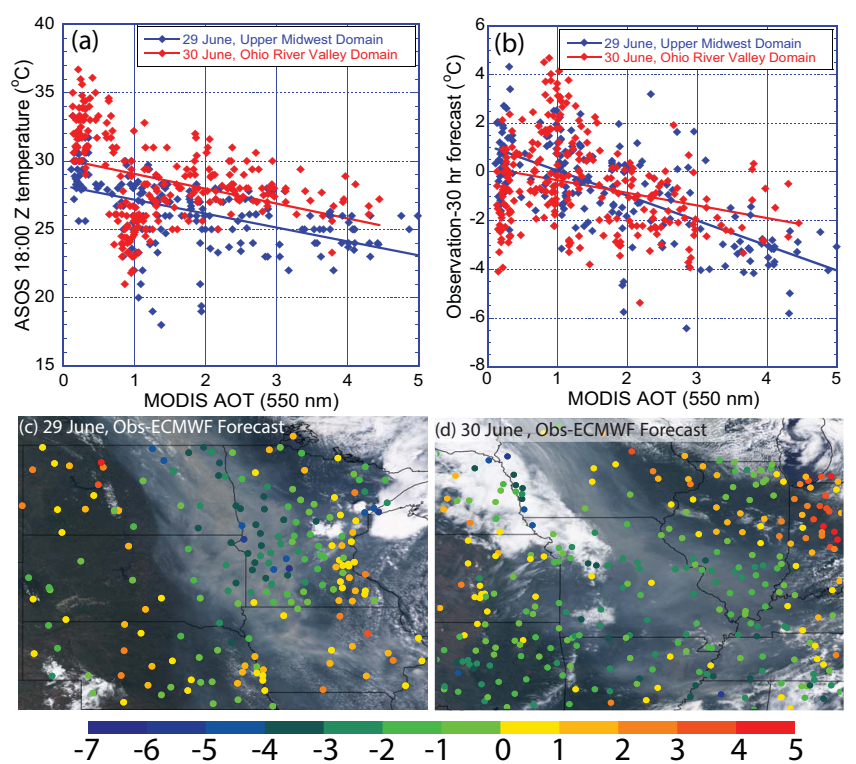

18:00 Z temperature difference, obs-forecast $\left({ }^{\circ} \mathrm{C}\right)$

Figure 7. (a) The observed near-surface air temperature and (b) the differences in observed and ECMWF $30 \mathrm{~h}$ forecasted near-surface air temperature $\left(\Delta T_{30 \mathrm{~h}}\right)$ as a function of MODIS DT $\tau_{550}$ for both the 29 June and the 30 June case. (c) RGB image over the upper Midwest on 29 June 2015, constructed using Terra MODIS level $1 \mathrm{~B}$ data. $\Delta T_{30 \mathrm{~h}}$ values from each ASOS station are overplotted on Fig. 7c. (d) Similar to panel (c) but over the Ohio River Valley on 30 June 2015.

\subsubsection{The 29 June case}

The 29 June 2015 case is an ideal case for studying the impact of the smoke plume on numerical-model-forecasted near-surface air temperatures for a few reasons. Firstly, both surface and satellite observations are in close proximity in time (15 min) to the 18:00 UTC model forecasts and analysis. Secondly, the thick smoke plume is not expected by the model and has not been accounted for in numerical model simulations.

Certainly over the region, there is a clear relationship between 18:00 Z measured temperature ( $\left.T_{\mathrm{obs}}\right)$ and MODIS $\tau_{550}$ (Fig. 7a). In general, temperature is reduced by $1{ }^{\circ} \mathrm{C}$ per unit 
$\tau_{550}$. However, there are exceptions, notably a drop in temperature for a cluster of data points of at $\tau_{550}$ of $\sim 1$. This group of data points belongs to sites on the eastern side of the 29 June upper Midwest domain, associated with the great lakes and lake country of Wisconsin (as is also evident in Fig. 3). Thus, we must be careful to acknowledge that there is a natural overall east to west positive temperature gradient on this day. Indeed, for the \pm 15 day period surrounding but excluding the event (Fig. 3g), Wisconsin is generally $1-4^{\circ}$ cooler. Excluding these cooler data points, the overall tendency is $1-2{ }^{\circ} \mathrm{C}$ per unit $\tau_{550}$. We consider this $1-2{ }^{\circ} \mathrm{C}$ per unit $\tau_{550}$ set of values to be the range of observational sensitivity.

As the next step, we attempt to control for the gradient in temperature using the forecast model itself. Fig. $7 \mathrm{~b}$ presents the ASOS 18:00 Z observation minus the ECMWF $30 \mathrm{~h}$ forecast against MODIS $\tau_{550}$. The values of this difference are also spatially mapped in Fig. 7c. Here, in corroboration with the pure observations from Fig. 7a, there is a trend for forecast temperature overestimation with $\tau_{550}$, on the order of $\sim 1$ to $2^{\circ} \mathrm{C}$. Use of the ECMWF forecast error in the analysis clearly mitigates a significant amount of the non-plumerelated temperature gradient across the domain. Temperatures in the heavy smoke plume region tended to be over forecasted by 1 to $6^{\circ} \mathrm{C}$. Conversely, on either side of the smoke plume, the $30 \mathrm{~h}$ forecast tends to underestimate temperature by $\sim 1$ to $2{ }^{\circ} \mathrm{C}$, leading to an overall temperature difference of -2 to $-8^{\circ} \mathrm{C}$, only slightly lower than the findings of a similar study by Westphal and Toon (1991). As an example, Grand Forks had a 18:00 Z maximum temperature of $23.9^{\circ} \mathrm{C}$ with a MODIS $\tau_{550}$ of 4.4, in comparison to the ECMWF forecast of $26.8^{\circ} \mathrm{C}$.

We can expand this analysis further, to examine the skill of ECMWF 18:00 Z analyses and 54 h forecasts relative to the $30 \mathrm{~h}$ forecast discussed above. Figure $8 \mathrm{a}-\mathrm{c}$ show the $0 \mathrm{~h}$ analysis, and 30 and $54 \mathrm{~h}$ forecasts of the $2 \mathrm{~m}$ air temperatures from ECMWF. Again, over the Grand Forks region at 18:00 UTC, the actual surface temperature is around $23.9^{\circ} \mathrm{C}$. In comparison, the analysis, $30 \mathrm{~h}$ forecast, and $54 \mathrm{~h}$ forecasts were $25.2,26.8$, and $28.2^{\circ} \mathrm{C}$ respectively (or $\sim 1.3,2.9$, and $4.3^{\circ} \mathrm{C}$ difference). This is not surprising, as (shown later in Table 6) a much smaller forecasting error is expected for the $0 \mathrm{~h}$ forecast. Expanding for all data in the domain, Fig. 8d$\mathrm{f}$ show the differences between observed and modeled $2 \mathrm{~m}$ air temperatures $\left(\Delta T_{0 \mathrm{~h}}, \Delta T_{30 \mathrm{~h}}\right.$ and $\left.\Delta T_{54 \mathrm{~h}}\right)$ as a function of MODIS $\tau_{550}$. In all cases clear relationships are found. U1timately, smoke-induced cooling for the $54 \mathrm{~h}$ and $30 \mathrm{~h}$ forecasts and the analysis are $-0.9^{\circ} \mathrm{C} / \tau_{550},-1.0^{\circ} \mathrm{C} / \tau_{550}$, and $-0.6^{\circ} \mathrm{C} / \tau_{550}$, respectively. The slope and offset values are also shown in Table 4.

The same analysis is also conducted for the analysis and 24 and $48 \mathrm{~h}$ forecasts of $1.5 \mathrm{~m}$ air temperatures from the UKMO model, and the 0,24 , and $48 \mathrm{~h}$ forecasts of $2 \mathrm{~m}$ air temperatures from the NCEP model. Similar results, as shown in Fig. 8a-f for ECMWF, are found and are summa-

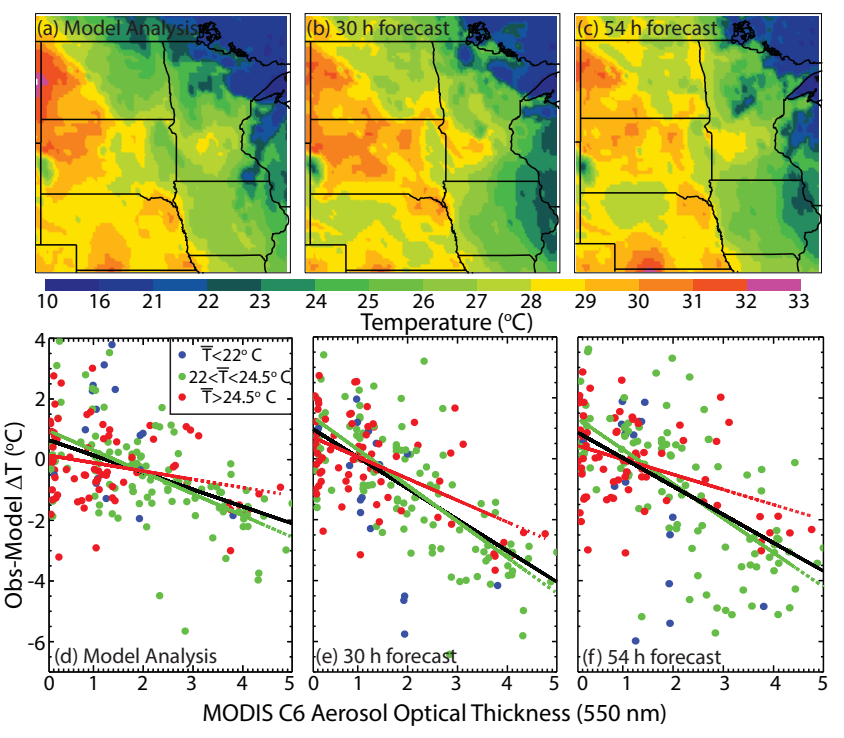

Figure 8. (a-c) 0, 30, and $54 \mathrm{~h}$ forecasts of $2 \mathrm{~m}$ air temperatures for the study region as shown in Fig. 3a at 18:00 UTC, 29 June 2015 from ECMWF model runs. (d-f). The differences between surface observations (using ground stations as shown in Fig. 3c) and ECMWF-modeled $2 \mathrm{~m}$ temperatures (at 18:00 UTC, 29 June 2015) as a function of Collection 6 Terra MODIS DT $\tau_{550}$. Data pairs are colored based on the observed monthly mean surface temperatures at 18:00 UTC as shown in Fig. 3g. Data pairs for regions with monthly mean temperatures of $<22^{\circ} \mathrm{C}$, between 22 and $24.5^{\circ} \mathrm{C}$ and $>24.5^{\circ} \mathrm{C}$ are colored in blue, green, and red respectively. Red dashed lines are the linear fit lines to the data pairs with red colors, and green dashed lines are the linear fit lines for data pairs with green colors.

rized in Table 4. Similar plots as Fig. 8 are provided in Appendix Figs. A1 and A2 for UKMO and NCEP respectively. For these other models, smoke-induced cooling values range from -0.3 to $-0.8^{\circ} \mathrm{C} / \tau_{550}$ for the analysis and 24 and $48 \mathrm{~h}$ forecasts from UKMO and NCEP models. Figure 8 and Table 4 suggest that a clear relationship exists between the differences in observed and modeled near-surface air temperature $(\Delta T)$ and $\tau_{550}$, for the $0,24(30)$, and $48(54) \mathrm{h}$ forecasts, regardless of the model evaluated. All nine cases suggest a daytime smoke aerosol direct surface cooling efficiency $\left(C_{\tau}\right)$ on the order of -0.4 to $-0.8^{\circ} \mathrm{C} / \tau_{550}(550 \mathrm{~nm})$ for $18: 00 \mathrm{Z}$ analyses, and -0.3 to $-1.0^{\circ} \mathrm{C} / \tau_{550}$ for 24 to $54 \mathrm{~h}$ forecasts, although the slopes could be biased by uncertainties in the numerical simulations.

In addition to statistical noise, variability in the daytime smoke $C_{\tau}$ could be a function of aerosol properties (e.g., absorption), surface characteristics, and the mixed layer (e.g., stability and advection). From the AERONET data in the region (Table 2), optical properties appear to be consistent over the region. Thus surface or regional attributes are likely a larger source of variability here. We hypothesized that such variability may covary with mean regional surface tempera- 
Table 4. Offsets $\left({ }^{\circ} \mathrm{C}\right)$ and slopes $\left({ }^{\circ} \mathrm{C} / \tau_{550}\right)$ of MODIS $\tau_{550}$ vs. the differences between observed (using ground stations as shown in Fig. $7 \mathrm{c}$ ) and modeled near-surface air temperatures (at 18:00 UTC, 29 June 2015) from ECMWF, UKMO, and NCEP model runs. Similar results using only stations with monthly mean temperatures $(\bar{T})$ within the range of 22 to $24.5^{\circ} \mathrm{C}$, as well as for stations with $\bar{T}>24.5^{\circ} \mathrm{C}$ are also shown.

\begin{tabular}{lrrr}
\hline Offset/slope & $\begin{array}{r}\mathrm{ECMWF} \\
\left({ }^{\circ} \mathrm{C}\right) /\left({ }^{\circ} \mathrm{C} / \tau_{550}\right)\end{array}$ & $\begin{array}{r}\mathrm{UKMO} \\
\left({ }^{\circ} \mathrm{C}\right) /\left({ }^{\circ} \mathrm{C} / \tau_{550}\right)\end{array}$ & $\begin{array}{r}\mathrm{NCEP} \\
\left({ }^{\circ} \mathrm{C}\right) /\left({ }^{\circ} \mathrm{C} / \tau_{550}\right)\end{array}$ \\
\hline 0h forecast & $0.70 /-0.56$ & $0.15 /-0.38$ & $-0.39 /-0.81$ \\
$\left(22{ }^{\circ} \mathrm{C}<\bar{T}<24.5^{\circ} \mathrm{C}\right)$ & $(1.03 /-0.72)$ & $(0.22 /-0.46)$ & $(-0.47 /-0.86)$ \\
$\left(\bar{T}>24.5^{\circ} \mathrm{C}\right)$ & $(0.17 /-0.27)$ & $(0.06 /-0.14)$ & $(-0.31 /-0.45)$ \\
\hline $24(30) \mathrm{h}$ forecast & $1.08 /-1.02$ & $-0.40 /-0.71$ & $0.62 /-0.55$ \\
$\left(22^{\circ} \mathrm{C}<\bar{T}<24.5^{\circ} \mathrm{C}\right)$ & $(1.49 /-1.18)$ & $(0.51 /-1.01)$ & $(-0.83 /-0.68)$ \\
$\left(\bar{T}>24.5^{\circ} \mathrm{C}\right)$ & $(0.77 /-0.71)$ & $(-0.92 /-0.36)$ & $(0.93 /-0.16)$ \\
\hline $48(54) \mathrm{h}$ forecast & $0.96 /-0.93$ & $0.03 /-0.67$ & $0.18 /-0.31$ \\
$\left(22{ }^{\circ} \mathrm{C}<\bar{T}<24.5^{\circ} \mathrm{C}\right)$ & $(1.44 /-1.13)$ & $(0.75 /-0.88)$ & $(0.72 /-0.52)$ \\
$\left(\bar{T}>24.5^{\circ} \mathrm{C}\right)$ & $(0.48 /-0.50)$ & $(-0.37 /-0.54)$ & $(0.31 / 0.04)$ \\
\hline
\end{tabular}

ture. In Fig. 8 , the scatter plots of $\Delta T$ vs. $\tau_{550}$ are also plotted as a function of monthly mean temperature at 18:00 UTC. To construct the monthly mean temperatures at 18:00 UTC for each ASOS site, daily observations within $\pm 10 \mathrm{~min}$ of 18:00 UTC are averaged to represent the daily surface temperature at 18:00 UTC. Then, those daily 18:00 UTC values are averaged over the study period of 15 June-14 July 2015, excluding observations from 29 June 2015 (Fig. 3g). Only ASOS sites having more than 20 daily averages are used. Data pairs with monthly mean temperatures lower than $22^{\circ} \mathrm{C}$, between 22 and $24.5^{\circ} \mathrm{C}$, and greater than $24.5^{\circ} \mathrm{C}$ (arbitrarily selected numbers) are colored in blue, green, and red, respectively. Data points are largely scattered for the cooler temperatures, representing the far eastern region of the domain. However, steeper slopes are found for middle temperature sites in comparison to those with warmer temperatures. Similar behaviors are also found for all UKMO and NCEP model forecasts and analyses (Table 4). This suggests that a higher absolute daytime smoke $C_{\tau}$ is expected for areas with monthly mean temperatures of $22-24.5^{\circ} \mathrm{C}$ in comparison with regions that are typically warmer. On the other hand, a higher absolute daytime smoke $C_{\tau}$ is expected for a colder region or a colder season. This topic will be further explored in a companion paper.

\subsubsection{The 30 June case}

The second day of the event, 30 June, is less ideal in comparison with the 29 June case, as the smoke plume is less dense, clouds form within the region, and the $\tau_{550}$ field has a smaller spatial gradient. Additionally, the Terra MODIS satellite overpasses are approximate $1 \mathrm{~h}$ ahead of the model data at 18:00 UTC, and one should expect that both aerosol and temperature fields may change within $1 \mathrm{~h}$. However, as an occluded front was moving into the Dakotas, the entire smoke air mass transited fairly uniformly into the Upper Mis- sissippi River Valley. Thus it is an interesting analysis to make.

Aerosol-induced surface cooling, while noisier, is nevertheless observable as shown in Fig. 7. Figure 7d shows a Terra MODIS RGB image of the 30 June case over the Upper Mississippi and Ohio Valley region. Similar to 29 June, Fig. $7 \mathrm{a}$ and $\mathrm{b}$ include the scatter plots of regional $T_{\mathrm{obs}}$ and $\Delta T_{30 \mathrm{~h}}$ vs. Terra MODIS DT $\tau_{550}$. On average, there is a $2{ }^{\circ} \mathrm{C}$ decrease in $\Delta T_{30 \mathrm{~h}}$ for an increase in MODIS $\tau_{550}$ to 4 , roughly half the 29 June sensitivity. Examining the ECMWF $30 \mathrm{~h}$ forecast, the model has low biases in the great lakes region, which in part leads to this suppressed value.

As shown in Sect. 3.4.1, similar analyses are conducted for the ECMWF-, UKMO-, and NCEP-modeled near-surface air temperatures for the Mississippi and Ohio Valley region, as shown in Table 5. Again, smoke-aerosol-induced surface cooling is found for all nine scenarios $(0,24$, and $48 \mathrm{~h}$ forecasts for UKMO and NCEP, 0,30 , and $54 \mathrm{~h}$ forecasts for ECMWF). However, smaller daytime smoke $C_{\tau}$ values on the order of -0.25 to $-0.5^{\circ} \mathrm{C} / \tau_{550}$ are found for the 30 June case in comparison with the 29 June case. The smaller daytime smoke $C_{\tau}$ values may be partially due to a larger temporal difference between the model and satellite data for the 30 June case; but again, this may also be a result of a difference in the atmosphere, and atmospheric simulation in the Great Lakes region.

In addition, as suggested from Sect. 3.4.1, it is possible that daytime smoke $C_{\tau}$ could be a function of surface temperature in itself. Compared to the upper Midwest region, the Mississippi and Ohio River Valley are at lower latitudes with warmer surface temperatures on average, and thus may experience a smaller $C_{\tau}$. To test this hypothesis, monthly mean surface air temperatures at 18:00 UTC are computed from ASOS data, following similar steps mentioned in Sect. 3.4.1, but with 30 June 2015 instead of 29 June 2015 excluded from the monthly averages (Fig. 3h). With the constructed monthly 
Table 5. Offsets $\left({ }^{\circ} \mathrm{C}\right)$ and slopes $\left({ }^{\circ} \mathrm{C} / \tau_{550}\right)$ of MODIS $\tau_{550}$ vs. the differences between observed (using ground stations as shown in Fig. $7 \mathrm{~d}$ ) and modeled near-surface air temperatures (at 18:00 UTC, 30 June 2015) from ECMWF, UKMO, and NCEP model runs. Similar results for stations with monthly mean temperatures $(\bar{T})$ less than $28^{\circ} \mathrm{C}$ are also shown.

\begin{tabular}{lrrr}
\hline Offset/slope & $\begin{array}{r}\mathrm{ECMWF} \\
\left({ }^{\circ} \mathrm{C}\right) /\left({ }^{\circ} \mathrm{C} / \tau_{550}\right)\end{array}$ & $\begin{array}{r}\mathrm{UKMO} \\
\left({ }^{\circ} \mathrm{C}\right) /\left({ }^{\circ} \mathrm{C} / \tau_{550}\right)\end{array}$ & $\begin{array}{r}\mathrm{NCEP} \\
\left({ }^{\circ} \mathrm{C}\right) /\left({ }^{\circ} \mathrm{C} / \tau_{550}\right)\end{array}$ \\
\hline $0 \mathrm{~h}$ forecast & $-0.01 /-0.29$ & $0.08 /-0.25$ & $-0.60 /-0.17$ \\
$\left(\bar{T}<28{ }^{\circ} \mathrm{C}\right)$ & $(0.24 /-0.41)$ & $(0.27 /-0.43)$ & $(-0.14 /-0.33)$ \\
\hline $24(30) \mathrm{h}$ forecast & $0.18 /-0.52$ & $-1.27 /-0.30$ & $0.78 /-0.42$ \\
$\left(\bar{T}<28{ }^{\circ} \mathrm{C}\right)$ & $(1.76 /-1.05)$ & $(-0.57 /-0.57)$ & $(1.61 /-0.62)$ \\
\hline $48(54) \mathrm{h}$ forecast & $0.17 /-0.20$ & $-1.46 /-0.29$ & $1.20 /-0.44$ \\
$\left(\bar{T}<28^{\circ} \mathrm{C}\right)$ & $(1.70 /-0.63)$ & $(-0.94 /-0.59)$ & $(1.67 /-0.50)$ \\
\hline
\end{tabular}

mean temperatures for available ASOS stations, the smoke aerosol $C_{\tau}$ values are recomputed for all nine scenarios (Table 5), but with the use of only ASOS stations that have monthly mean temperatures lower than $28^{\circ} \mathrm{C}$. Lower daytime smoke $C_{\tau}$ values on the order of -0.5 to $-1.0^{\circ} \mathrm{C} / \tau_{550}$ are found by restricting the study region to colder areas. Still, these are only potential possibilities for the differences between the 29 and 30 June cases.

\subsection{Cooling efficiencies as related to baseline uncertainties for the modeled near-surface air temperature}

The question of how important the smoke cooling efficiency is to numerical weather prediction is fundamentally related to the overall skill of the natural model. Models with large root-mean-square errors (RMSEs) will mask the aerosol signal; such models have more important sources of error. Models with high skill, on the other hand, naturally are sensitive to higher order terms. In this section, we examine this phenomenon and by evaluating near-surface air temperature forecasts from ECMWF, UKMO, and NCEP in the upper Midwest region with respect to smoke $\tau_{550}$ for the 29 June case. As the first step, baseline uncertainties in nearsurface air temperatures from NCEP, UKMO, and ECMWF model runs are evaluated (Table 6) using surface observations from ground stations, as shown in Fig. 3g. To construct Table 6, 0-, 24(30), and 48(54) h model forecasts at 18:00 UTC from 15 June to 14 July are collocated with ground-based ASOS data (the numbers included in parentheses are for ECMWF). The means of the differences between observed and forecasted temperatures are computed for the 0,24(30), and 48(54) $\mathrm{h}$ model forecasts and are represented by $\Delta T_{0 \mathrm{~h}}$, $\Delta T_{24 / 30 \mathrm{~h}}$, and $\Delta T_{48 / 54 \mathrm{~h}}$, respectively, in this study. Indicated in Table 6 , similar $\Delta T_{48 / 54 \mathrm{~h}}$ values of around $-1{ }^{\circ} \mathrm{C}$ with similar 1 standard deviation of $\sim 2.5^{\circ} \mathrm{C}$ are found for the $48 \mathrm{~h}$ forecasted near-surface air temperatures from UKMO and NCEP. A smaller $\Delta T_{48 / 54 \mathrm{~h}}$ of $-0.4{ }^{\circ} \mathrm{C}$, with a smaller 1 standard deviation of $2.0^{\circ} \mathrm{C}$, is found for the $54 \mathrm{~h}$ forecasted $2 \mathrm{~m}$ air temperatures from ECMWF. $\Delta T_{24 / 30 \mathrm{~h}}$ and 1 standard derivation of $\Delta T_{24 / 30 \mathrm{~h}}$ of around -0.8 and $2.3^{\circ} \mathrm{C}$ are found for the $24 \mathrm{~h}$ forecasted $2 \mathrm{~m}$ air temperatures for NCEP, and the values are -0.6 and $2.1{ }^{\circ} \mathrm{C}$ for the $24 \mathrm{~h}$ forecasted $1.5 \mathrm{~m}$ air temperatures for UKMO. Again, smaller values of $\Delta T_{24 / 30 \mathrm{~h}}$ and 1 standard derivation of -0.2 and $1.9^{\circ} \mathrm{C}$ are found for the $30 \mathrm{~h}$ forecasted $2 \mathrm{~m}$ air temperatures for ECMWF. In comparison, the $0 \mathrm{~h}$ forecasts of near-surface air temperatures exhibit much smaller standard derivations of the differences to the observed surface temperatures; around $1.5^{\circ} \mathrm{C}$ from all three models.

The root-mean-square error (RMSE) values for the 0 , 24(30), and 48(54) h model-forecasted near-surface air temperatures are $2.3,2.5$, and $2.7^{\circ} \mathrm{C}$ for NCEP data, 1.3, 2.2, and $2.7^{\circ} \mathrm{C}$ for UKMO, and $1.6,1.9$, and $2.0^{\circ} \mathrm{C}$ for ECMWF model runs, respectively. The same analysis has also been conducted for the 30 June 2015 case. Not surprisingly, the reported RMSE values are consistent for both the upper Midwest and the Ohio River Valley regions. For example, the computed RMSE values for the 30 June case are 1.5, 2.0, and $2.2{ }^{\circ} \mathrm{C}$ for the 0,30 , and $54 \mathrm{~h}$ ECMWF forecasts. The RMSE values for the 0,24 , and $48 \mathrm{~h}$ NCEP and UKMO model forecasted near-surface air temperatures are $1.9,2.2,2.5^{\circ} \mathrm{C}$, and $1.3,2.1,2.5^{\circ} \mathrm{C}$, respectively.

The RMSE values represent the baseline cases for the modeled uncertainty in near-surface air temperatures. Theoretically, the effect of aerosols on weather forecasts can likely be detected if the aerosol-induced surface cooling is larger than the baseline uncertainties in the modeled near-surface air temperatures. Given a rough estimation of $\sim-1.5^{\circ} \mathrm{C} / \tau_{550}$ for the daytime smoke $C_{\tau}$, the changes in $\tau_{550}$ need to be above $\sim 1.5-2$ for the aerosol-induced cooling effect to be observable from the $48(54) \mathrm{h}$ model forecasts. Similarly, $\tau_{550}$ values of $\sim 1-1.5$ and $\sim 1.5$ are required for the aerosolinduced cooling effect to be detectable from the 0 and 24(30) h model forecasts. 
Table 6. The means and 1 standard deviations (1 SD) of the differences in observed and modeled near-surface air temperatures $\left(T_{\text {ground-FC }}\right)$ for 0-, 24-, and $48 \mathrm{~h}(0,30$, and $54 \mathrm{~h}$ for ECMWF) forecasts for NCEP, UKMO, and ECMWF model runs over the upper Midwest region. The modeled data are compared with surface temperature measurements from ground stations as shown in Fig. $3 \mathrm{~g}$ for the period of $15 \mathrm{June}-$ 14 July 2015 (excluding 29 June 2015 data).

\begin{tabular}{|c|c|c|c|c|c|c|c|c|c|}
\hline & \multicolumn{3}{|c|}{$\begin{array}{c}\text { ECMWF } \\
\left({ }^{\circ} \mathrm{C}\right)\end{array}$} & \multicolumn{3}{|c|}{$\begin{array}{l}\text { UKMO } \\
\left({ }^{\circ} \mathrm{C}\right) \\
\end{array}$} & \multicolumn{3}{|c|}{$\begin{array}{c}\text { NCEP } \\
\left({ }^{\circ} \mathrm{C}\right) \\
\end{array}$} \\
\hline & Analysis & $30 \mathrm{~h}$ & $54 \mathrm{~h}$ & Analysis & $24 \mathrm{~h}$ & $48 \mathrm{~h}$ & Analysis & $24 \mathrm{~h}$ & $48 \mathrm{~h}$ \\
\hline$T_{\text {ground-FC }}$ & -0.2 & -0.2 & -0.4 & 0.0 & -0.6 & -0.8 & -1.5 & -0.8 & -1.0 \\
\hline 1-SD & 1.5 & 1.9 & 2.0 & 1.3 & 2.1 & 2.5 & 1.8 & 2.3 & 2.5 \\
\hline RMSE & 1.6 & 1.9 & 2.0 & 1.3 & 2.2 & 2.7 & 2.3 & 2.5 & 2.7 \\
\hline
\end{tabular}

\section{Application: straw assessment on a global scale}

It is suggested from Sect. 3 that smoke aerosol plumes have a daytime $C_{\tau}$ on the order of $\sim-0.25$ to $-1.5^{\circ} \mathrm{C} / \tau_{550}$; yet RMSE values estimated over the study region for the modeled near-surface air temperatures from NCEP, UKMO, and ECMWF are on the order of $1.3-2.3^{\circ} \mathrm{C}$ for $0 \mathrm{~h}$ forecasts and are much larger for a longer period of forecasts. Clearly, even with the inclusion of perfect aerosol fields in numerical models, the impact of aerosol particles on near-surface temperature forecasts are unlikely to be observable due to the inherent uncertainties in numerical model simulations. An exception to this is a region experiencing very high AOTs, in particular a sharp change in aerosol loading of a significant amount (e.g., daily $\tau_{550}$ change $>1$ for aerosol effects to be observable from $0 \mathrm{~h}$, near-surface air temperature forecasts).

Next, we assume the $\sim-1.5^{\circ} \mathrm{C} / \tau_{550}$ daytime $C_{\tau}$ is applicable to all aerosol types and the estimated RMSE values from over the study region are applicable on a global scale. Regions whose near-surface air temperature forecasts could potentially be affected by aerosol plumes with a detectable signal are studied. Note that only sharp daily changes in AOT can introduce detectable signals in weather forecasts: for a region with persistent high aerosol loading, the aerosol cooling effects are likely to be accounted for through assimilating meteorological-based observations that are impacted by aerosol particles. As mentioned above, for the aerosol direct cooling effect to be detectable on $0 \mathrm{~h}$ near-surface air temperature forecasts, a minimum sharp daily $\tau_{550}$ change of approximately 1 is required. Therefore, using 1 year of Collection 6 MODIS Dark Target (DT) and Deep Blue (DB) aerosol products from both Aqua and Terra, we have studied regions that have sharp daily AOT changes above 1 .

For illustration purposes, Fig. 9a and b show the spatial distribution of yearly mean MODIS AOT and the number of days with MODIS $\tau_{550}$ larger than 1, respectively, at a spatial resolution of $0.5^{\circ}$ (latitude/longitude), constructed using C6 Aqua and Terra aerosol products for 2014. The combined DT and DB data, which are included in C6 MODIS aerosol products, are used. Additionally, "bad" retrievals, as indicated by
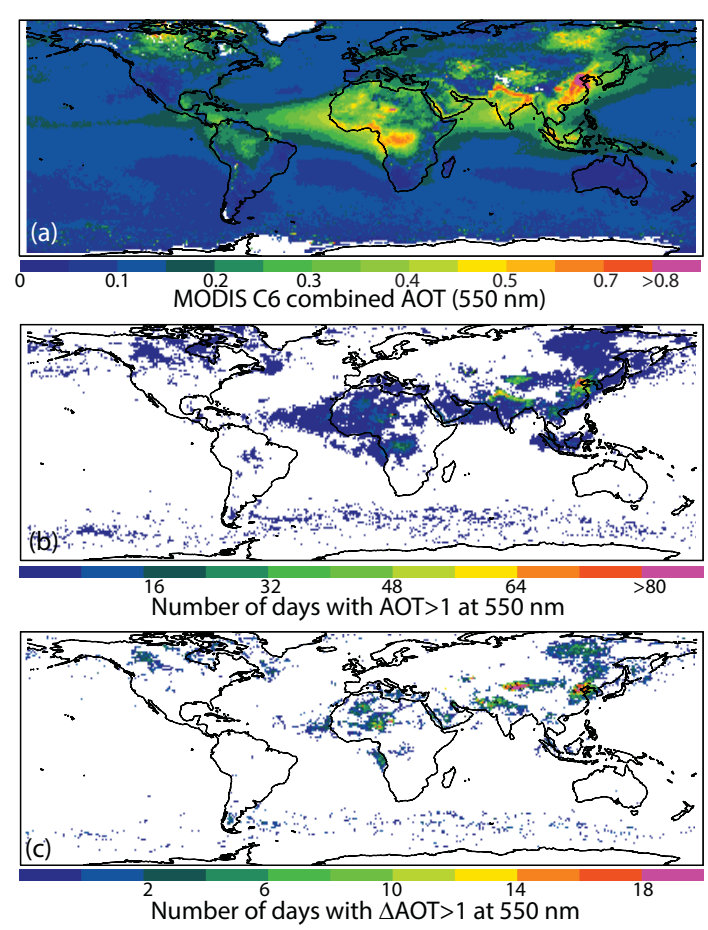

Figure 9. (a) Yearly averaged, $0.5 \times 0.5^{\circ}$ (latitude/longitude) binned $\tau_{550}$ from the Collection 6 Aqua and Terra MODIS combined DT and DB aerosol products for 2014; (b) the number of days with daily mean MODIS $\tau_{550}$ larger than 1 for a given $0.5 \times 0.5^{\circ}$ (latitude/longitude) bin; (c) the number of cases when an absolute change in daily MODIS $\tau_{550}$ of above 1 is detected from two contiguous days for a given $0.5 \times 0.5^{\circ}$ (latitude/longitude) bin.

the quality assurance flag included in the products, are discarded.

The global yearly average $\tau_{550}$, as shown in Fig. 9a, is consistent with the spatial $\tau_{550}$ distributions as reported from previous studies (e.g., Levy et al., 2013; Zhang and Reid, 2010). In addition, not surprisingly, regions with MODIS $\tau_{550}$ larger than 1 (Fig. 9b), which include central and northern Africa, the Middle East, India, eastern Asia, southeastern Asia, and upper North America. In particular, over India and eastern China, the number of $\tau_{550}$-larger-than- 1 days exceeds 
2 months, indicating potential severe aerosol pollution issues for the two regions.

Using the MODIS aerosol products as shown in Fig. 9a and $\mathrm{b}$, the $0.5^{\circ}$ (latitude/longitude) gridded daily AOT data from a given day are compared with the gridded daily AOT data from the next day. If a change in $\tau_{550}$ of larger than 1.0 is found for a $0.5^{\circ}$ (latitude/longitude) grid box, the event is recorded. Figure 9(c) shows the global distribution of the number of cases when sharp changes of $\tau_{550}$ of $>1$ are detected for a $0.5^{\circ}$ (latitude/longitude) grid box. A total of 1 year (2014) of Terra and Aqua combined DT and DB $\tau_{550}$ data are used. However, the average number of cases with sharp $\tau_{550}$ changes are rather low in general, indicating that even by incorporating an accurate aerosol field in a numerical model, the aerosol-induced surface cooling effect would remain mostly undetected for the $0 \mathrm{~h}$ forecast due to relatively larger uncertainties in modeled near-surface air temperatures. Still, Fig. 9c suggests that for regions such as eastern China, eastern Russia, India, and portions of the Saharan and Taklamakan deserts, sharp changes in $\tau_{550}$ of above 1 happen more than 10 times a year. These are the regions where incorporating aerosol models is likely to have the most impact on weather forecasts of near-surface air temperatures.

Lastly, readers should be aware that aerosol plumes with extreme high aerosol loadings could be misidentified as clouds; thus these aerosol plumes could be excluded from the MODIS DT/DB retrievals (e.g., Alfaro-Contreras et al., 2016). Therefore, the frequency distribution of the sharp aerosol loading changes, as shown in Fig. 9c, is likely underestimated. Still, this is the first attempt at such efforts, and is worth reporting.

\section{Conclusions and implications}

In this study, the effect of smoke aerosol plumes on $2 \mathrm{~m}$ $(1.5 \mathrm{~m}$ for the UKMO model) air temperature forecasts from European Centre for Medium-Range Weather Forecasts (ECMWF), National Centers for Environmental Prediction (NCEP), and United Kingdom Meteorological Office (UKMO) models are investigated over a significant smoke aerosol event that happened on 28-30 June 2015 over the Midwestern United States. The smoke-aerosol-induced daytime direct surface cooling effect is studied and the baseline uncertainties in the modeled near-surface air temperatures are evaluated over the study domain. This study suggests the following.

1. Consistent with several previous studies, the 29 June 2015 smoke event introduced a noticeable surface cooling of $\sim 5^{\circ} \mathrm{C}$ over Grand Forks, ND. The smokeaerosol-induced daytime direct surface cooling efficiency $\left(C_{\tau}\right)$ is estimated to be $\sim-1.5^{\circ} \mathrm{C}$ per 1.0 AOT $\left(550 \mathrm{~nm}, \tau_{550}\right)$.
2. The differences in observed near-surface air temperatures and modeled $2 \mathrm{~m} / 1.5 \mathrm{~m}$ air temperatures from NCEP, UKMO, and ECMWF models $(\Delta T)$ are studied as a function of MODIS $\tau_{550}$ for 0,24 , and $48 \mathrm{~h}$ forecasts $(0,30$, and $54 \mathrm{~h}$ forecasts for the ECMWF model) for the 29 June 2015 smoke event. All nine cases show a clear decrease in $\Delta T$ as $\tau_{550}$ increases to 4 , indicating that the smoke event does have an observable cooling effect on the near-surface air temperature forecasts, with an estimated daytime $C_{\tau}$ on the order of -0.5 to $-1{ }^{\circ} \mathrm{C}$ per unit $\tau_{550}$. Those $C_{\tau}$ values are still likely to be affected by uncertainties in modeled temperatures.

3. Similar analysis was also conducted on 30 June 2015 over the Ohio River Valley. Again, the smoke-aerosolplume-induced surface cooling is found from all nine scenarios, however with a smaller (in magnitude) daytime $C_{\tau}$ on the order of -0.25 to $-0.5^{\circ} \mathrm{C}$ per unit $\tau_{550}$. Further analysis seems to indicate that $C_{\tau}$ may also be a function of surface temperature, and a smaller (in magnitude) daytime $C_{\tau}$ may be expected over a warmer region. This hypothesis will be further examined in a modeling-based paper.

4. Using 1 month of observed surface temperatures from the study region, baseline uncertainties for near-surface air temperatures from the $0,24(30)$, and $48(54) \mathrm{h}$ forecasts are estimated to be 1.3-2.3, 1.9-2.5, and 2.0$2.7^{\circ} \mathrm{C}$, respectively. Thus, for the aerosol-induced direct cooling effect to be observable from the $0 \mathrm{~h}$ model forecasted near-surface air temperature fields, a daily change in $\tau_{550}$ of $\sim 1.0-1.5(550 \mathrm{~nm})$ is needed. Similar requirements in $\tau_{550}$ of $\sim 1.5$ and $\sim 1.5-2.0$ are needed for the aerosol direct cooling effect to be detected from 24(30) and 48(54) h forecasted near-surface air temperature fields respectively, assuming the estimated daytime $C_{\tau}$ of $\sim-1.5^{\circ} \mathrm{C}$ per unit $\tau_{550}$ is applicable to all cases.

5. Using 1 year of Terra and Aqua Collection 6 MODIS combined Dark Target and Deep Blue aerosol products, the number of days with significant changes in daily $\tau_{550}$ of $>1$ are estimated. Globally, events with a daily $\tau_{550}$ change of $>1$ are rare, indicating that at the current stage, incorporating aerosol models in-line with a weather forecasting model is unlikely to introduce a noticeable improvement in the forecasted near-surface air temperatures. Still, for regions such as eastern China, eastern Russia, India, and portions of Saharan and Taklamakan deserts, the number of days with sharp $\tau_{550}$ changes is above 10 for the year 2014, showing that accurate aerosol analysis may be needed for weather forecasts for these regions.

6. Note that this study is focused on cloud-free conditions and only the direct smoke aerosol surface cooling effect 
is studied. Still, aerosol particles may indirectly affect weather by altering cloud microphysics in both stratiform and convective clouds (e.g., Tao et al., 2012). Such effects warrant further discussions and evaluations.

Through an observational-based analysis, this study suggests that aerosol particles do have an observable cooling effect on near-surface air temperatures. In a companion paper, the aerosol-induced direct cooling effect will be further explored from a modeling perspective with the use of a numerical model in-line with an aerosol transport model. Lastly, we expect, with the improvement in accuracy of numerical forecasting models in the future, that the inclusion of accurate aerosol estimates will be unavoidable for the further improvement of numerical weather forecasts.

\section{Data availability}

The deterministic forecasts from ECMWF were obtained from Angela Benedetti. All other data sources were obtained online with data links mentioned in the data set section (accessed on or before 1 December 2015). 


\section{Appendix A}
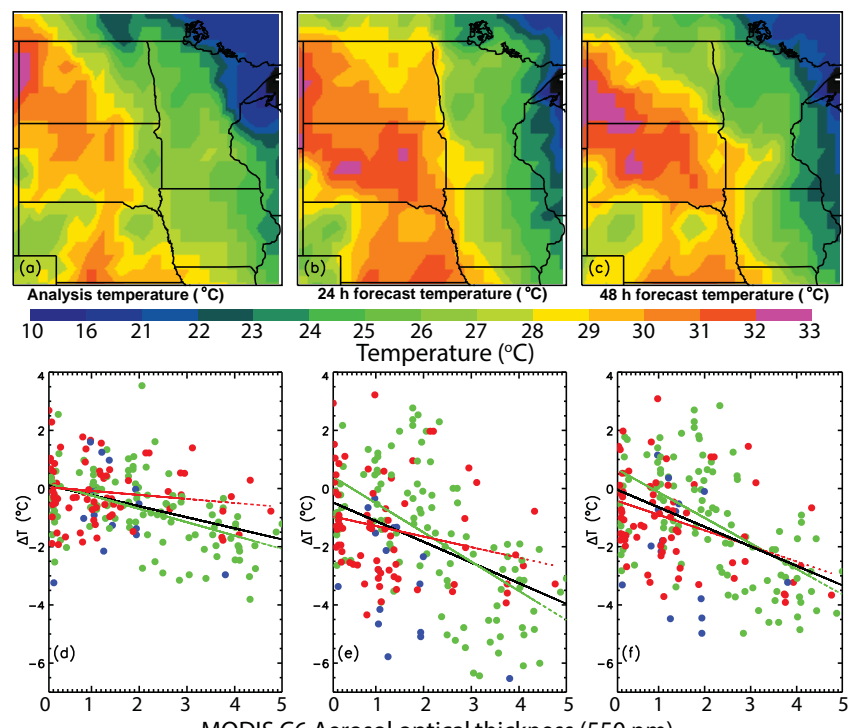

Figure A1. (a-c) 0, 24, and $48 \mathrm{~h}$ forecasts of $1.5 \mathrm{~m}$ air temperatures for the study region as shown in Fig. 3a at 18:00 UTC, 29 June 2015, from UKMO model runs. (d-f) The differences between surface observations (using ground stations as shown in Fig. 3c) and UKMO-modeled $1.5 \mathrm{~m}$ temperatures (at 18:00 UTC, 29 June 2015) as a function of Collection 6 Terra MODIS DT $\tau_{550}$. Data pairs are colored based on the observed monthly mean surface temperatures at 18:00 UTC as shown in Fig. 3g. Data pairs for regions with monthly mean temperatures of $<22^{\circ} \mathrm{C}$, between 22 and $24.5^{\circ} \mathrm{C}$ and $>24.5^{\circ} \mathrm{C}$ are colored in blue, green, and red respectively. Red dashed lines are the linear fit lines to the data pairs with red colors, and green dashed lines are the linear fit lines for data pairs with green colors.
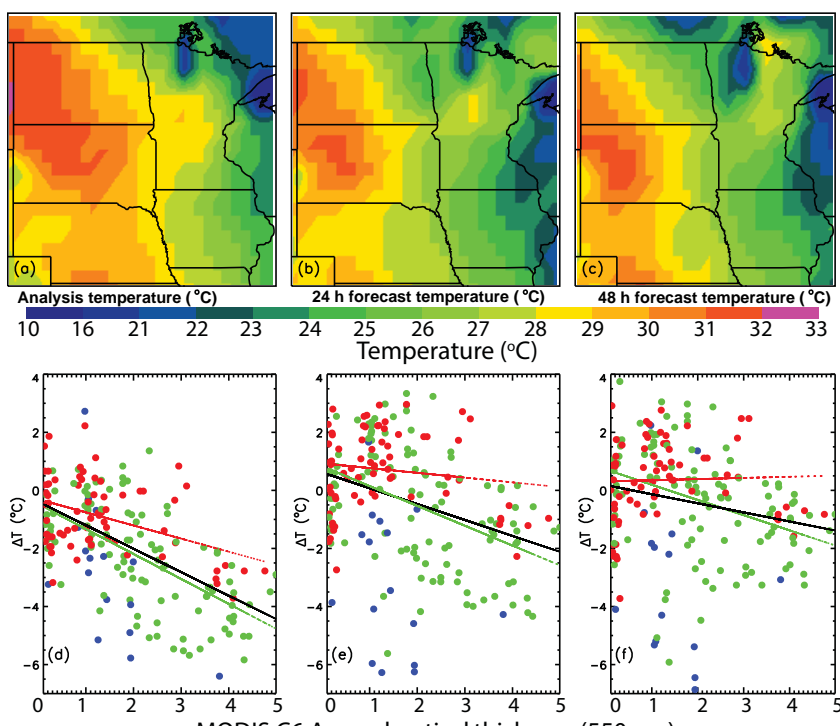

Figure A2. (a-c) 0, 24, and $48 \mathrm{~h}$ forecasts of $2 \mathrm{~m}$ air temperatures for the study region as shown in Fig. 3a at 18:00 UTC, 29 June 2015, from NCEP model runs. (d-f) The differences between surface observations (using ground stations as shown in Fig. 3c) and NCEPmodeled $2 \mathrm{~m}$ temperatures (at 18:00 UTC, 29 June 2015) as a function of Collection 6 Terra MODIS DT $\tau_{550}$. Others are similar to Fig. A1. 
Acknowledgements. Authors Jianglong Zhang and Matthew Christensen acknowledge the support of the NASA project NNX14AJ13G and the NSF project IIA-1355466. Author Jeffrey S. Reid was supported by ONR Code 322 (N0001415WX00854). We thank the THORPEX Interactive Grand Global Ensemble (TIGGE) group for the NCEP and UK Met Office model data. We thank the Iowa Environmental Mesonet (IEM) for surface-based meteorological observations. We also thank the AERONET program and their affiliated members for the surface-based aerosol optical property measurements. We further thank Morgan M. Simms for obtaining NWS related weather data. Editorial support from E. A. Reid is gratefully acknowledged.

Edited by: H. Wang

\section{References}

Adhikary, B., Kulkarni, S., Dallura, A., Tang, Y., Chai, T., Leung, L. R., Qian, Y., Chung, C. E., Ramanathan, V., and Carmichael, G. R.: A regional scale chemical transport modeling of Asian aerosols with data assimilation of AOD observations using optimal interpolation technique, Atmos. Environ., 42, 8600-8615, 2008.

Alfaro-Contreras, R., Zhang, J., Campbell, J. R., and Reid, J. S.: Investigating the frequency and interannual variability in global above-cloud aerosol characteristics with CALIOP and OMI, Atmos. Chem. Phys., 16, 47-69, doi:10.5194/acp-16-47-2016, 2016.

Benedetti, A., Morcrette, J.-J., Boucher, O., Dethof, A., Engelen, R. J., Fisher, M., Flentje, H., Huneeus, N., Jones, L., Kaiser, J. W., Kinne, S., Mangold, A., Razinger, M., Simmons, A. J., and Suttie, M.: Aerosol analysis and forecast in the European Centre for Medium-Range Weather Forecasts Integrated Forecast System: 2. Data assimilation, J. Geophys. Res., 114, D13205, doi:10.1029/2008JD011115, 2009.

Bougeault P., Toth, Z., Bishop, C., Brown, B., Burridge, D., Chen, D. H., Ebert, B., Fuentes, M., Hamill, T. M., Mylne, K., Nicolau, J., Paccagnella, T., Park, Y.-Y., Parsons, D., Raoult, B., Schuster, D., Silva Dias, P., Swinbank, R., Takeuchi, Y., Tennant, W., Wilson, L., and Worley, S.: The THORPEX interactive grand global ensemble, B. Am. Meteorol. Soc., 91, 1059-1072, 2010.

Chapman, E. G., Gustafson Jr., W. I., Easter, R. C., Barnard, J. C., Ghan, S. J., Pekour, M. S., and Fast, J. D.: Coupling aerosolcloud-radiative processes in the WRF-Chem model: Investigating the radiative impact of elevated point sources, Atmos. Chem. Phys., 9, 945-964, doi:10.5194/acp-9-945-2009, 2009.

Chew, B. N., Campbell, J. R., Reid, J. S., Giles, D. M., Welton, E. J., Salinas, S. V., and Liew, S. C: Tropical cirrus cloud contamination in sun photometer data, Atmos. Environ., 45, 6724-6731, doi:10.1016/j.atmosenv.2011.08.017, 2011.

Colarco, P. R., Schoeberl, M. R., Doddridge, B. G., Marufu, L. T., Torres, O., and Welton, E. J.: Transport of smoke from Canadian forest fires to the surface near Washington, D.C.: Injection height, entrainment, and optical properties, J. Geophys. Res., 109, D06203, doi:10.1029/2003JD004248, 2004.

Colarco, P., da Silva, A., Chin, M., and Diehl, T.: Online simulations of global aerosol distributions in the NASA GEOS-4 model and comparisons to satellite and ground-based aerosol optical depth,
J. Geophys. Res., 115, D14207, doi:10.1029/2009JD012820, 2010.

Collins, W. D., Rasch, P. J., Eaton, B. E., Khattatov, B. V., Lamarque, J.-F., and Zender, C. S.: Simulating aerosols using a chemical transport model with assimilation of satellite aerosol retrievals: Methodology for INDOEX, J. Geophys. Res., 106, 7313-7336, doi:10.1029/2000JD900507, 2001.

Cook, J. and Highwood, E. J.: Climate response to tropospheric absorbing aerosols in an intermediate general-circulation model, Q. J. Roy. Meteor. Soc., 130, 175-191, doi:10.1256/qj.03.64, 2004.

Dee, D. P., Uppala, S. M., Simmons, A. J., Berrisford, P., Poli, P., Kobayashi, S., Andrae, U., Balmaseda, M. A., Balsamo, G., Bauer, P., Bechtold, P., Beljaars, A. C. M., van de Berg, L., Bidlot, J., Bormann, N., Delsol, C., Dragani, R., Fuentes, M., Geer, A. J., Haimberger, L., Healy, S. B., Hersbach, H., Hólm, E. V., Isaksen, L., Kållberg, P., Köhler, M., Matricardi, M., McNally, A. P., Monge-Sanz, B. M., Morcrette, J.-J., Park, B.-K., Peubey, C., de Rosnay, P., Tavolato, C., Thépaut, J.-N., and Vitart, F.: The ERA-Interim reanalysis: Configuration and performance of the data assimilation system, Q. J. Roy. Meteor. Soc., 137, 553-597, doi:10.1002/qj.8, 2011.

Draxler, R. R. and Hess, G. D.: Description of the HYSPLIT_4 modeling system, NOAA Tech. Memo. ERL ARL-224, NOAA Air Resources Laboratory, Silver Spring, MD, USA, 24 pp., 1997.

Dubovik, O. and King, M. D.: A flexible inversion algorithm for the retrieval of aerosol optical properties from Sun and sky radiance measurements, J. Geophys. Res., 105, 20673-20696, doi:10.1029/2000JD900282, 2000.

Ge, C., Wang, J., and Reid, J. S.: Mesoscale modeling of smoke transport over the Southeast Asian Maritime Continent: coupling of smoke direct radiative effect below and above the low-level clouds, Atmos. Chem. Phys., 14, 159-174, doi:10.5194/acp-14159-2014, 2014.

Generoso, S., Bréon, F.-M., Chevallier, F., Balkanski, Y., Schulz, M., and Bey, I.: Assimilation of POLDER aerosol optical thickness into the LMDz-INCA model: Implications for the Arctic aerosol burden, J. Geophys. Res., 112, D02311, doi:10.1029/2005JD006954, 2007.

Grell, G., Freitas, S. R., Stuefer, M., and Fast, J.: Inclusion of biomass burning in WRF-Chem: impact of wildfires on weather forecasts, Atmos. Chem. Phys., 11, 5289-5303, doi:10.5194/acp11-5289-2011, 2011.

Holben, B. N., Eck, T. F., Slutsker, I., Tanré, D., Buis, J. P., Setzer, A., Vermote, E., Reagan, J. A., Kaufman, Y. J., Nakajima, T., Lavenu, F., Jankowiak, I., and Smirnov, A.: AERONET - A Federated Instrument Network and Data Archive for Aerosol Characterization, Remote Sens. Environ., 66, 1-16, 1998.

Hsu, N. C., Jeong, M.-J., Bettenhausen, C., Sayer, A. M., Hansell, R., Seftor, C. S., Huang, J., and Tsay, S.-C.: Enhanced Deep Blue aerosol retrieval algorithm: The second generation, J. Geophys. Res.-Atmos., 118, doi:10.1002/jgrd.50712, 2013.

Intergovernmental Panel on Climate Change (IPCC): The Physical Science Basis, Working Group I Contribution to the IPCC Fifth Assessment Report Climate Change 2013, Geneva, Switzerland, available at: http://www.ipcc.ch/report/ar5/wg1/\#.UqgAXQSiSo (last access: 1 December 2015), 2013.

Jacobson, M. Z.: Effects of biomass burning on climate, accounting for heat and moisture fluxes, black and brown carbon, and 
cloud absorption effects, J. Geophys. Res.-Atmos., 119, 89809002, doi:10.1002/2014JD021861, 2014.

Jacobson, M. Z. and Kaufman, Y. J.: Wind reduction by aerosol particles, Geophys. Res. Lett., 33, L24814, doi:10.1029/2006GL027838, 2006.

Justice, C. O., Giglio, L., Korontzi, S., Owens, J., Morisette, J. T., Roy, D., Descloitres, J., Alleaume, S., Petitcolin, F., and Kaufman, Y. J.: The MODIS fire products, Remote Sens. Environ., 83, 244-262, 2002.

Kahn, R. A., Gaitley, B. J., Garay, M. J., Diner, D. J., Eck, T. F., Smirnov, A., and Holben, B. N.: Multiangle Imaging SpectroRadiometer global aerosol product assessment by comparison with the Aerosol Robotic Network, J. Geophys. Res., 115, D23209, doi:10.1029/2010JD014601, 2010.

Kahnert, M.: Variational data analysis of aerosol species in a regional CTM: background error covariance constraint and aerosol optical observation operators, Tellus B, 60, 753-770, doi:10.1111/j.1600-0889.2008.00377.x, 2008.

Kaku, K. C., Reid, J. S., O’Neill, N. T., Quinn, P. K., Coffman, D. J., and Eck, T. F.: Verification and application of the extended spectral deconvolution algorithm (SDA+) methodology to estimate aerosol fine and coarse mode extinction coefficients in the marine boundary layer, Atmos. Meas. Tech., 7, 3399-3412, doi:10.5194/amt-7-3399-2014, 2014.

Kolusu, S. R., Marsham, J. H., Mulcahy, J., Johnson, B., Dunning, C., Bush, M., and Spracklen, D. V.: Impacts of Amazonia biomass burning aerosols assessed from short-range weather forecasts, Atmos. Chem. Phys., 15, 12251-12266, doi:10.5194/acp-15-12251-2015, 2015.

Kukkonen, J., Olsson, T., Schultz, D. M., Baklanov, A., Klein, T., Miranda, A. I., Monteiro, A., Hirtl, M., Tarvainen, V., Boy, M., Peuch, V.-H., Poupkou, A., Kioutsioukis, I., Finardi, S., Sofiev, M., Sokhi, R., Lehtinen, K. E. J., Karatzas, K., San José, R., Astitha, M., Kallos, G., Schaap, M., Reimer, E., Jakobs, H., and Eben, K.: A review of operational, regional-scale, chemical weather forecasting models in Europe, Atmos. Chem. Phys., 12, 1-87, doi:10.5194/acp-12-1-2012, 2012.

Lau, K.-M. and Kim, K.-M.: Observational relationships between aerosol and Asian monsoon rainfall, and circulation, Geophys. Res. Lett., 33, L21810, doi:10.1029/2006GL027546, 2006.

Levy, R. C., Mattoo, S., Munchak, L. A., Remer, L. A., Sayer, A. M., Patadia, F., and Hsu, N. C.: The Collection 6 MODIS aerosol products over land and ocean, Atmos. Meas. Tech., 6, 29893034, doi:10.5194/amt-6-2989-2013, 2013.

Lin, C., Wang, Z., and Zhu, J.: An Ensemble Kalman Filter for severe dust storm data assimilation over China, Atmos. Chem. Phys., 8, 2975-2983, doi:10.5194/acp-8-2975-2008, 2008.

Mulcahy, J. P., Walters, D. N., Bellouin, N., and Milton, S. F.: Impacts of increasing the aerosol complexity in the Met Office global numerical weather prediction model, Atmos. Chem. Phys., 14, 4749-4778, doi:10.5194/acp-14-4749-2014, 2014.

Niu, T., Gong, S. L., Zhu, G. F., Liu, H. L., Hu, X. Q., Zhou, C. H., and Wang, Y. Q.: Data assimilation of dust aerosol observations for the CUACE/dust forecasting system, Atmos. Chem. Phys., 8, 3473-3482, doi:10.5194/acp-8-3473-2008, 2008.

O’Neill, N. T., Eck, T. F., Smirnov, A., Holben, B. N., and Thulasiraman, S.: Spectral discrimination of coarse and fine mode optical depth, J. Geophys. Res., 108, 4559, doi:10.1029/2002JD002975, 2003.
O’Neill, N. T., Campanelli, M., Lupu, A., Thulasiraman, S., Reid, J. S., Aube, M., Neary, L., Kaminski, J. W., and McConnel, J. C.: Evaluation of the GEM-AQ air quality model during the Quebec smoke event of 2002: Analysis of extensive and intensive optical disparities, Atmos. Environ., 40, 3737-3749, 2005.

Pagowski, M. and Grell, G. A.: Experiments with the assimilation of fine aerosols using an ensemble Kalman filter, J. Geophys. Res.-Atmos., 117, D21302, doi:10.1029/2012jd018333, 2012.

Pérez, C., Nickovic, S., Pejanovic, G., Baldasano, J. M., and Özsoy, E.: Interactive dust-radiation modeling: A step to improve weather forecasts, J. Geophys. Res., 111, D16206, doi:10.1029/2005JD006717, 2006.

Pérez, C., Haustein, K., Janjic, Z., Jorba, O., Huneeus, N., Baldasano, J. M., Black, T., Basart, S., Nickovic, S., Miller, R. L., Perlwitz, J. P., Schulz, M., and Thomson, M.: Atmospheric dust modeling from meso to global scales with the online NMMB/BSC-Dust model - Part 1: Model description, annual simulations and evaluation, Atmos. Chem. Phys., 11, 1300113027, doi:10.5194/acp-11-13001-2011, 2011.

Reid, J. S., Eck, T. F., Christopher, S. A., Koppmann, R., Dubovik, O., Eleuterio, D. P., Holben, B. N., Reid, E. A., and Zhang, J.: A review of biomass burning emissions part III: intensive optical properties of biomass burning particles, Atmos. Chem. Phys., 5, 827-849, doi:10.5194/acp-5-827-2005, 2005.

Rémy, S., Benedetti, A., Bozzo, A., Haiden, T., Jones, L., Razinger, M., Flemming, J., Engelen, R. J., Peuch, V. H., and Thepaut, J. N.: Feedbacks of dust and boundary layer meteorology during a dust storm in the eastern Mediterranean, Atmos. Chem. Phys., 15, 12909-12933, doi:10.5194/acp-15-12909-2015, 2015.

Robock, A.: Surface cooling due to forest fire smoke, J. Geophys. Res., 96, 20869-20878, doi:10.1029/91JD02043, 1991.

Rubin, J. I., Reid, J. S., Hansen, J. A., Anderson, J. L., Collins, N., Hoar, T. J., Hogan, T., Lynch, P., McLay, J., Reynolds, C. A., Sessions, W. R., Westphal, D. L., and Zhang, J.: Development of the Ensemble Navy Aerosol Analysis Prediction System (ENAAPS) and its application of the Data Assimilation Research Testbed (DART) in support of aerosol forecasting, Atmos. Chem. Phys., 16, 3927-3951, doi:10.5194/acp-16-3927-2016, 2016.

Schutgens, N. A. J., Miyoshi, T., Takemura, T., and Nakajima, T.: Applying an ensemble Kalman filter to the assimilation of AERONET observations in a global aerosol transport model, Atmos. Chem. Phys., 10, 2561-2576, doi:10.5194/acp-10-25612010, 2010.

Sessions, W. R., Reid, J. S., Benedetti, A., Colarco, P. R., da Silva, A., Lu, S., Sekiyama, T., Tanaka, T. Y., Baldasano, J. M., Basart, S., Brooks, M. E., Eck, T. F., Iredell, M., Hansen, J. A., Jorba, O. C., Juang, H.-M. H., Lynch, P., Morcrette, J.-J., Moorthi, S., Mulcahy, J., Pradhan, Y., Razinger, M., Sampson, C. B., Wang, J., and Westphal, D. L.: Development towards a global operational aerosol consensus: basic climatological characteristics of the International Cooperative for Aerosol Prediction MultiModel Ensemble (ICAP-MME), Atmos. Chem. Phys., 15, 335362, doi:10.5194/acp-15-335-2015, 2015.

Shi, Y., Zhang, J., Reid, J. S., Holben, B., Hyer, E. J., and Curtis, C.: An analysis of the collection 5 MODIS over-ocean aerosol optical depth product for its implication in aerosol assimilation, Atmos. Chem. Phys., 11, 557-565, doi:10.5194/acp-11-557-2011, 2011. 
Tanaka, T. Y. and Chiba, M.: Global simulation of dust aerosol with a chemical transport model, MASINGAR, J. Meteorol. Soc. Jpn., 83, 255-278, 2005.

Tao, W.-K., Chen J.-P., Li Z., Wang C., and Zhang C.: Impact of aerosols on convective clouds and precipitation, Rev. Geophys., 50, RG2001, doi:10.1029/2011RG000369, 2012.

Tesfaye, M., Tsidu, G. M., Botai, J., Sivakumar, V., and Rautenbach, C. J. D.: Mineral dust aerosol distributions, its direct and semidirect effects over South Africa based in regional climate model simulations, J. Arid Environ., 114, 22-40, 2015.

Todey, D. P., Herzmann, D. E., and Takle, G. S.: The Iowa Environmental Mesonet - combining networks into a single network, Preprints 6th Symposium on Integrated Observing Systems, Annual Meeting of the American Meteorological Society, 14-17 January 2002, Orlando, FL, USA, 2002.

Tombette, M., Chazette, P., Sportisse, B., and Roustan, Y.: Simulation of aerosol optical properties over Europe with a 3-D sizeresolved aerosol model: comparisons with AERONET data, Atmos. Chem. Phys., 8, 7115-7132, doi:10.5194/acp-8-7115-2008, 2008.

Westphal, D. L. and Toon, O. B.: Simulations of microphysical, radiative, and dynamical processes in a continental-scale forest fire smoke plume, J. Geophys. Res., 96, 22379-22400, doi:10.1029/91JD01956, 1991.
Yu, H., Dickinson, R. E., Chin, M., Kaufman, Y. J., Holben, B. N., Geogdzhayev, I. V., and Mishchenko, M. I.: Annual cycle of global distributions of aerosol optical depth from integration of MODIS retrievals and GOCART model simulations, J. Geophys. Res., 108, 4128, doi:10.1029/2002JD002717, 2003.

Zhang, J. and Reid, J. S.: A decadal regional and global trend analysis of the aerosol optical depth using a data-assimilation grade over-water MODIS and Level 2 MISR aerosol products, Atmos. Chem. Phys., 10, 10949-10963, doi:10.5194/acp-1010949-2010, 2010.

Zhang, J., Reid, J. S., Westphal, D. L., Baker, N. L., and Hyer, E. J.: A system for operational aerosol optical depth data assimilation over global oceans, J. Geophys. Res., 113, D10208, doi:10.1029/2007JD009065, 2008.

Zhang, J., Campbell, J. R., Reid, J. S., Westphal, D. L., Baker, N. L., Campbell, W. F., and Hyer, E. J.: Evaluating the impact of assimilating CALIOP-derived aerosol extinction profiles on a global mass transport model, Geophys. Res. Lett., 38, L14801, doi:10.1029/2011GL047737, 2011.

Zhang, J., Reid, J. S., Campbell, J. R., Hyer, E. J., and Westphal, D. L.: Evaluating the Impact of Multi-Sensor Data Assimilation on A Global Aerosol Particle Transport Model, J. Geophys. Res.Atmos., 119, 4674-4689, doi:10.1002/2013JD020975, 2014. 